\title{
5-酰基巴比妥酸衍生物的设计、合成及除草活性和分子作用机制研究
}

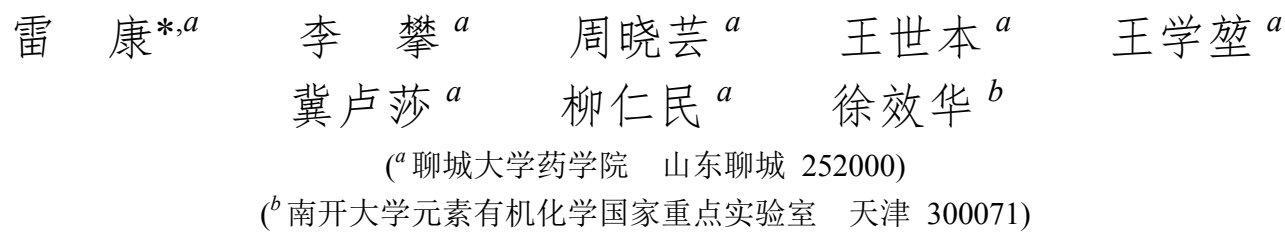

\begin{abstract}
摘要 为了开发含有巴比妥酸结构的新型 $\beta$-三酮类除草剂, 设计、合成了一系列 5 -酰基巴比妥酸衍生物, 并测试了其 除草活性. 温室盆栽测试结果表明, 在 $1500 \mathrm{~g} \cdot \mathrm{ha}^{-1}$ 的剂量下，目标化合物 1,3-二甲基-5-(2-(2-氯-4-氟苯氧基)-1-羟基亚 乙基)嘧啶-2,4,6(1H,3H,5H)-三酮(BBA-22)和 1,3-二甲基-5-(2-(2-澳-4-氟苯氧基)-1-羊基亚乙基)嘧啶-2,4,6(1H,3H,5H)-三 酮(BBA-27)对所测杂草均具有优异的抑制活性. 其中, 化合物 BBA-22 在苗前处理 $187.5 \mathrm{~g} \cdot \mathrm{ha}^{-1}$ 的剂量下, 对油菜、苋 菜和马唐具有很好的抑制活性，其活性优于商品除草剂 2,4-二氯苯氧乙酸(2,4-D). 另外，以拟南芥为模型植物的分子作 用机制研究表明, 化合物 BBA-22 在植物体中被降解为相应的苯氧乙酸, 这解释了其与生长素类除草剂具有相似除草 机理的原因. 本工作的研究结果表明, 化合物 BBA-22 是其相应的苯氧乙酸生长素类除草剂的前药, 可以用作进一步开 发新型生长素型除草剂的先导化合物.
\end{abstract}

关键词 $\beta$-三酮; 5-酰基巴比妥酸; 合成; 除草剂; 苯氧乙酸

\section{Design, Synthesis and Herbicidal Activity of 5-Acylbarbituric Acid Derivatives and Study of Molecular Mode of Action}

\author{
Lei, Kang ${ }^{*, a}$ \\ $\mathrm{Li}, \operatorname{Pan}^{a}$ \\ Zhou, Xiaoyun $^{a}$ \\ Wang, Shiben ${ }^{a}$ \\ Wang, Xuekun ${ }^{a}$ \\ Ji, Lusha ${ }^{a}$ \\ Liu, Renmin ${ }^{a}$ \\ $\mathrm{Xu}, \mathrm{Xiaohua}^{b}$ \\ $\left({ }^{a}\right.$ School of Pharmacy, Liaocheng University, Liaocheng, Shandong 252000) \\ $\left({ }^{b}\right.$ State Key Laboratory of Elemento-organic Chemistry, Nankai University, Tianjin 300071)
}

\begin{abstract}
In an effort to develop novel $\beta$-triketone herbicides containing a barbituric acid moiety, a series of 5-acylbarbituric acid derivatives were designed, synthesized, and tested for herbicidal activity. The bioassay results showed that some of the target compounds, such as 5-(2-(2-chloro-4-fluorophenoxy)-1-hydroxyethylidene)-1,3-dimethylpyrimidine-2,4,6(1H,3H,5H)trione (BBA-22) and 5-(2-(2-bromo-4-fluorophenoxy)-1-hydroxyethylidene)-1,3-dimethylpyrimidine-2,4,6(1H,3H,5H)-trione (BBA-27), exhibited excellent herbicidal activity against all tested weeds at a dosage of $1500 \mathrm{~g} \bullet \mathrm{ha}^{-1}$. In particular, compound BBA-22 displayed good pre-emergent herbicidal activity against Brassica campestris, Amaranthus retroflexus and Digitaria sanguinalis even at a dosage of $187.5 \mathrm{~g} \cdot \mathrm{ha}^{-1}$, surpassing that of a commercial herbicide 2,4-dichlorophenoxyacetic acid (2,4-D). Investigation of the molecular mode of action of compound BBA-22 upon treatment of Arabidopsis thaliana as a model plant revealed that BBA-22 was degraded to the corresponding phenoxyacetic acid, which explains why the herbicidal mechanism is similar to that of auxin-type herbicides. The present study demonstrates that compound BBA-22 is a proherbicide of the corresponding phenoxyacetic acid auxin herbicide and a potential lead compound for further development of novel auxin herbicides.
\end{abstract}

Keywords $\beta$-triketone; 5-acylbarbituric acid; synthesis; herbicide; phenoxyacetic acid

\footnotetext{
* Corresponding author. E-mail: leikang@1cu.edu.cn

Received May 13, 2020; revised June 15, 2020; published online July 8, 2020

Project supported by the National Natural Science Foundation of China (Nos. 31701827, 81803360), the China Postdoctoral Science Foundation (No. 2020M671984), the Doctoral Research Startup Foundation of Liaocheng University (No. 318051647), the Innovation and Entrepreneurship Training Program for College Students of Liaocheng University (No. CXCY2020Y179) and the Natural Science Foundation of Shandong Province (Nos. ZR2019PC041, ZR2017BH037)

国家自然科学基金(Nos. 31701827, 81803360)、中国博士后科学基金(No. 2020M671984)、聊城大学博士科研启动基金(No. 318051647)、聊城大学大 学生创新创业训练(No. CXCY2020Y179)和山东省自然科学基金(Nos. ZR2019PC041, ZR2017BH037)资助项目.
} 


\section{Introduction}

The $\beta$-triketone skeleton is a basic structural feature of many natural products (Figure 1). ${ }^{[1-11]}$ Over the last few decades, compounds with a $\beta$-triketone skeleton have played an important role in the pharmaceutical and agrochemical fields because of the antioxidative, ${ }^{[12]}$ antiplasmodial, ${ }^{[13]}$ anti-inflammatory, ${ }^{[14]}$ antibacterial, ${ }^{[15,16]}$ antiviral, ${ }^{[17]}$ herbicidal, ${ }^{[18]}$ antifungal, ${ }^{[19-23]}$ and insecticidal activities. $^{[24]}$ Such characteristics of $\beta$-triketones have made them important, and numerous novel compounds with a $\beta$-triketone skeleton, mainly served as herbicides, have been synthesized in recent years. For example, Zhu et $a l^{[25]}$ have reported that $\beta$-triketones containing a $2 H$-benzo[b][1,4]oxazin-3(4H)-one moiety exhibited good herbicidal activity at a dosage of $375 \mathrm{~g} \bullet \mathrm{ha}^{-1}$. Yang et $a l^{[26-29]}$ have reported that $\beta$-triketones containing a quinazoline-2,4-dione, quinoline, or aryloxyacetyl moiety exhibited excellent herbicidal activity at a lower dosage.

Barbituric acid is a key intermediate in the synthesis of biologically active compounds, and the derivatives (Figure 2) with substituents in the 5-position have demonstrated anticancer, ${ }^{[30-31]}$ antibacterial, ${ }^{[32-33]}$ antifungal, ${ }^{[34]}$ antitubercular, ${ }^{[35-36]}$ anti-inflammatory, ${ }^{[37-38]}$ sedative-hypnotic and
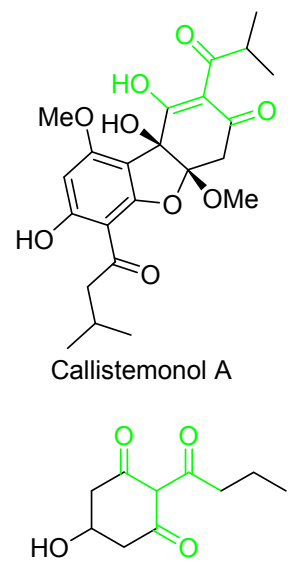

AB5046B

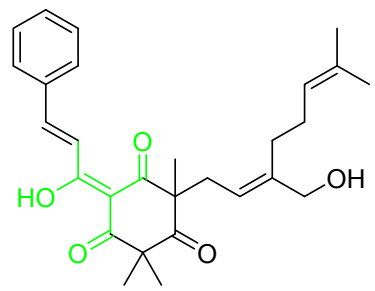

Cleistocaltones B

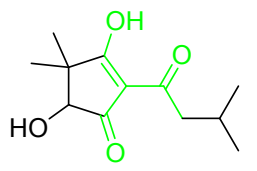

Callistemonol B anticonvulsant properties. ${ }^{[39-40]}$ Moreover, a number of compounds with a barbituric acid moiety are radiosensitizing agents, ${ }^{[41]}$ reactive oxygen scavengers, ${ }^{[42]}$ methionine aminopeptidase-1 inhibitors, ${ }^{[43]}$ and human immuno-deficiency virus-1 (HIV-1) and human immuno-deficiency virus-2 (HIV-2) (HIV-2) protease inhibitors. ${ }^{[44]}$ Although barbituric acid derivatives exhibit fascinating biological activities, relatively little is known about their application as herbicides. ${ }^{[45]}$ Recently, we ${ }^{[46-47]}$ constructed $\beta$-triketone derivatives by introducing an acyl group in the 3-positions of 4-hydroxy-6-methyl-2H-pyran2-one and 2,1-benzothiazine, and found that some compounds possessed good herbicidal activity. Inspired by our recent work, we anticipated that introducing an acyl group in the 5-position of barbituric acid can help construct $\beta$-triketone compounds containing a barbituric acid moiety (Figure 2), which should possess good herbicidal activity. Therefore, as a part of our continuous efforts to develop new $\beta$-triketone herbicides, ${ }^{[46,48]} 315$-acylbarbituric acid derivatives were synthesized and tested for herbicidal activity. Here, the synthesis, herbicidal activity, and structure-activity relationship of 5-acyl- barbituric acid derivatives, as well as the molecular mode of action study results were reported.

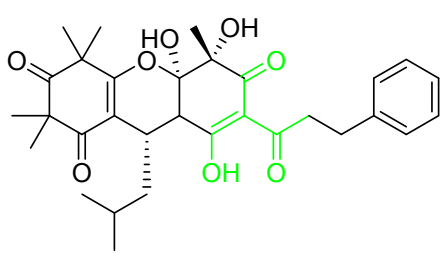

Watsonianone C<smiles>CC(=O)C1C(=O)CC(O)CC1=O</smiles><smiles>CC(C)CC(=O)C1C(=O)C(C)(C)C(=O)C(C)(C)C1=O</smiles>

Leptospermone
AB5046A

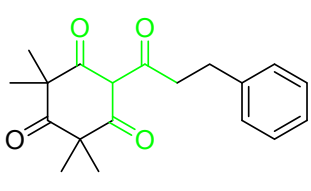

Grandiflorone

Figure 1 Examples of natural products containing a $\beta$-triketone skeleton

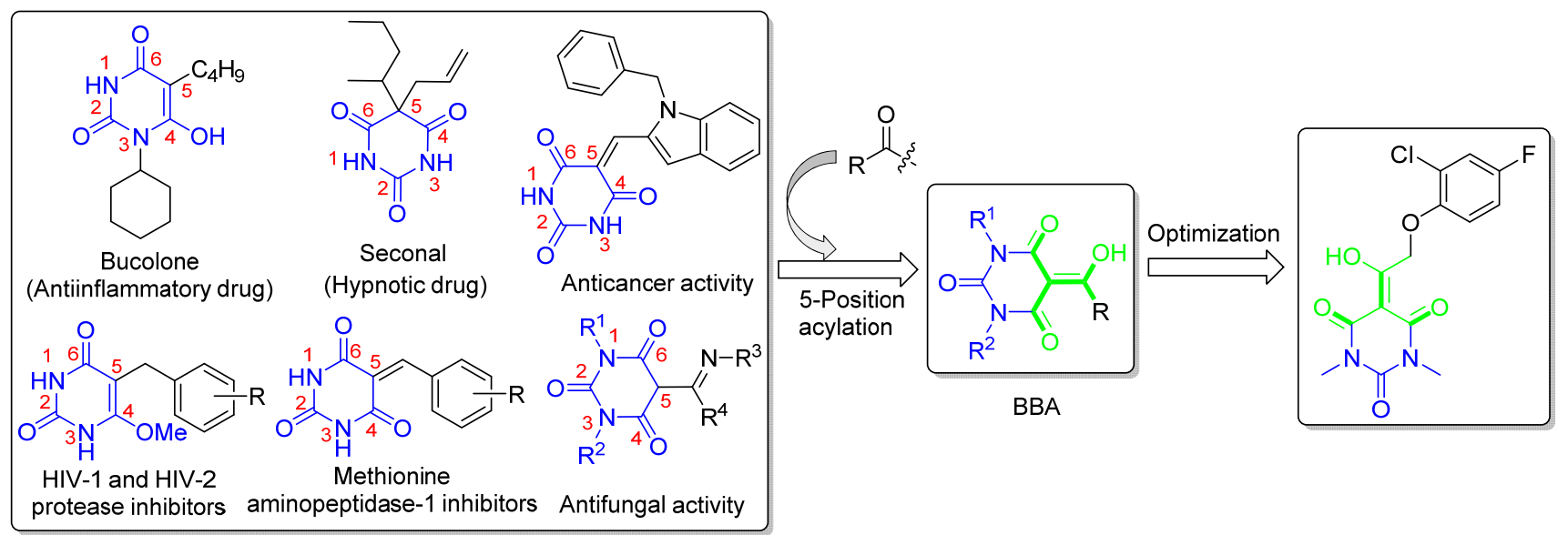

Figure 2 Design strategy of target compounds 


\section{Results and discussion}

\subsection{Chemistry}

As depicted in Scheme 1 (Route A), the target compounds BBA-1 $\sim$ BBA-6 were prepared via a two-step synthetic route. First, 1,3-dimethylpyrimidine-2,4,6(1H, $3 H, 5 H$ )-trione (3) was obtained in moderate yield by reacting 1,3-dimethylurea (1) with diethyl malonate (2) in absolute ethanol under basic conditions. Then, target compounds BBA-1 $\sim$ BBA-6 were synthesized in yield of $47.2 \% \sim 69.5 \%$ by condensation of 3 with a commercial acetyl chloride derivative 4 in the presence of trimethylamine. To obtain the target compounds BBA-7 $\sim$ BBA-31, the intermediate aryloxyacetyl chloride derivative $\mathbf{9}$ was first synthesized according to Scheme 1 (Route B). In the presence of potassium carbonate as a base, phenol $\mathbf{5}$ was reacted with methyl chloroacetate to yield the corresponding methyl aryloxyacetate 7. Subsequently, hydrolysis of methyl aryloxyacetate 7 with sodium hydroxide in a methanol/water system resulted in the corresponding aryloxyacetyl acid $\mathbf{8}$, which was reacted with oxalyl chloride in the presence of a catalytic amount of $N, N$-dimethylformamide (DMF) to produce the corresponding aryloxyacetyl chloride derivative 9. Finally, the condensation of compound 3 with aryloxyacetyl chloride 9 in the presence of trimethylamine afforded the target compounds BBA-7 BBA-31 in $34.7 \% \sim 63.3 \%$ yield.

The structures of all the target compounds were determined using ${ }^{1} \mathrm{H}$ NMR and ${ }^{13} \mathrm{C}$ NMR spectroscopy and HRMS. In addition, the structures of compounds BBA-27 and BBA-29 were confirmed by X-ray diffraction analysis (CCDC 2002865 and 2002866, Figure 3).

2.2 In vitro Herbicidal activity and evaluation of the molecular mode of action

For initial evaluation of the target compounds, the $B$. campestris root test and E. crusgalli cup test were performed. Mesotrione and 2,4-D were selected as positive controls. As shown in Figure 4, most compounds displayed good herbicidal activity against $B$. campestris at a dosage of $100 \mu \mathrm{g} \cdot \mathrm{mL}^{-1}$. Compounds BBA-10, BBA-18, BBA-22, BBA-23 and BBA-27 displayed $>90 \%$ growth control of B. campestris even at a dosage of $10 \mu \mathrm{g} \bullet \mathrm{mL}^{-1}$, which is comparable to that of a commercial herbicide 2,4-D and superior to that of mesotrione. However, most of the target compounds showed worse herbicidal activity against $E$. crusgalli. Only few compounds (BBA-2, BBA-3, BBA-22,

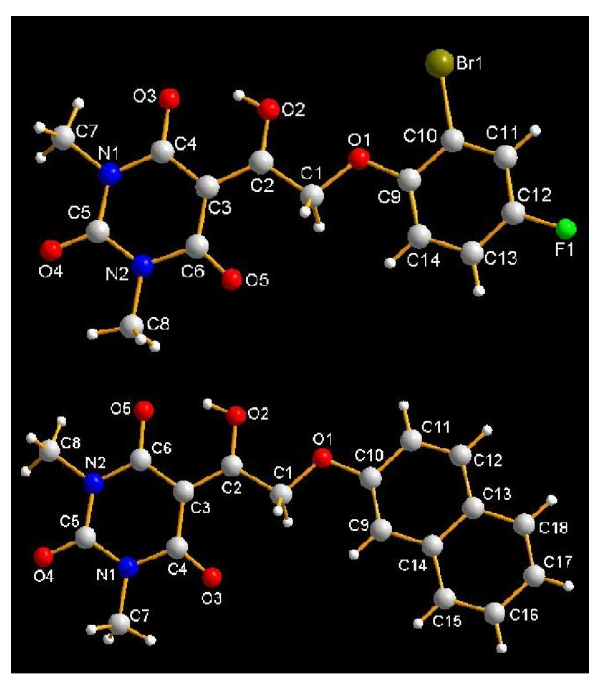

Figure 3 X-ray crystal structures of compounds BBA-27 (top) and BBA-29 (bottom)

and BBA-27) exhibited $>70 \%$ growth control of $E$. crusgalli at a dosage of $100 \mu \mathrm{g} \bullet \mathrm{mL}^{-1}$. These findings indicate that most of the target compounds exhibit better herbicide activity against dicotyledonous plants than that of monocotyledonous plants.

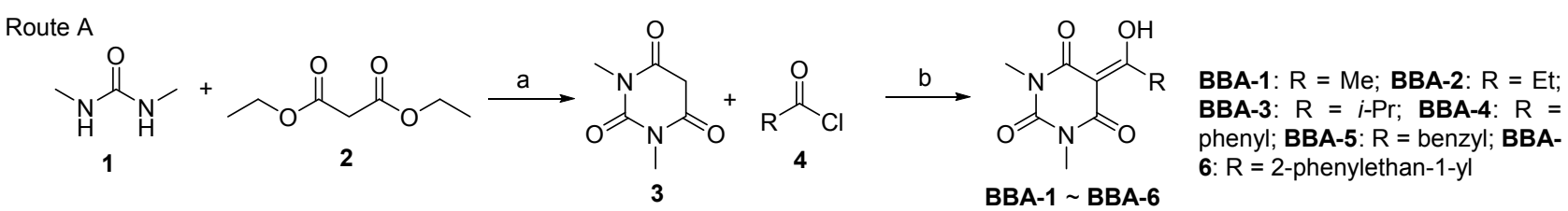

Route B<smiles>[R]O[O+][Na]</smiles><smiles>[R]OCC(=O)OCCCC</smiles><smiles>[R]OCC(=O)O</smiles><smiles>[R]OCC(=O)Cl</smiles>
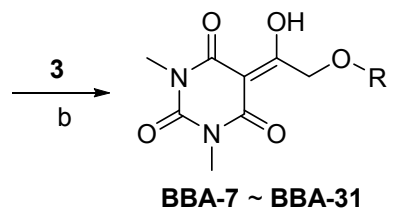

BBA-7: R = phenyl; BBA-8: R = 2-chlorophenyl; BBA-9: R = 3-chlorophenyl; BBA-10: $\mathrm{R}=$ 4-chlorophenyl; BBA-11: R = o-tolyl; BBA-12: $\mathrm{R}$ = $m$-tolyl; BBA-13: $\mathrm{R}=p$-tolyl; BBA-14: $\mathrm{R}=$ 2-trifluoromethylphenyl; BBA-15: $\mathrm{R}=$ 3-trifluoromethylphenyl; $\mathbf{B B A}-16$ : $\mathrm{R}=4$-trifluoromethylphenyl; BBA-17: $\mathrm{R}=$ 2,3-dichlorophenyl; BBA-18: $\mathrm{R}=2$,4-dichlorophenyl; BBA-19: $\mathrm{R}=2$,5-dichlorophenyl; $\mathbf{B B A - 2 0}$ : $\mathrm{R}=3,5$-dichlorophenyl; BBA21: $R=$ 2,6-dichlorophenyl; BBA-22: $R=$ 2-chloro-4-fluorophenyl; BBA-23: $R=$ 4-chloro-2-methylphenyl; BBA-24: $R=2,4$-dimethylphenyl; BBA-25: $R$ = 4-fluoro-2-methylphenyl; BBA-26: $R$ = 2-bromo-4-chlorophenyl; BBA-27: $\mathrm{R}$ = 2-bromo-4-fluorophenyl; BBA-28: $\mathrm{R}$ = 4-phenoxyphenyl; BBA-29: $R$ = naphthalen-2-yl; BBA-30: R = 1-bromonaphthalen-2-yl; BBA-31: $R$ = 1,6-dibromonaphthalen-2-yl

Regeant and conditions: (a) $\mathrm{NaOC}_{2} \mathrm{H}_{5} / \mathrm{C}_{2} \mathrm{H}_{5} \mathrm{OH}, 80{ }^{\circ} \mathrm{C}, 12 \mathrm{~h}$; (b) $\mathrm{Et}{ }_{3} \mathrm{~N}, \mathrm{DCM}, 25{ }^{\circ} \mathrm{C}, 24 \mathrm{~h}$; (c) methyl choloroformate, $\mathrm{K}_{2} \mathrm{CO}_{3}, \mathrm{DMF}, 50{ }^{\circ} \mathrm{C}, 12 \mathrm{~h}$; (d) $\mathrm{NaOH}, \mathrm{MeOH} / \mathrm{H}_{2} \mathrm{O}, 70{ }^{\circ} \mathrm{C}, 2 \mathrm{~h}$; (e) oxalyl chloride, DMF, DCM, $25{ }^{\circ} \mathrm{C}, 12 \mathrm{~h}$

Scheme 1 Synthetic route of target compounds BBA-1 $\sim$ BBA-31 

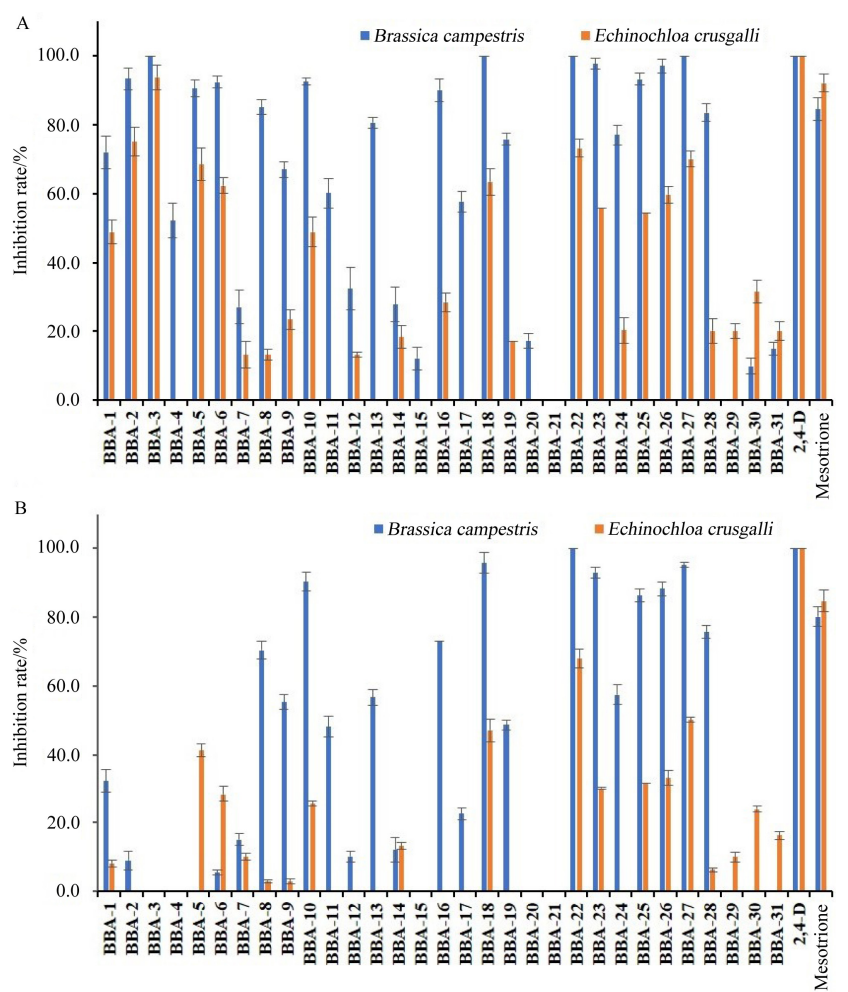

Figure 4 Inhibition of mustard root and barnyard grass seedling growth by BBA-1 $\sim$ BBA-31 at concentrations of (A) $100 \mu \mathrm{g} \cdot$ $\mathrm{mL}^{-1}$ and (B) $10 \mu \mathrm{g} \bullet \mathrm{mL}^{-1}$ (error bars represent standard deviation from three biological replicates)

Furthermore, it was found that the herbicidal activity of the target compounds was significantly influenced by the $\mathrm{R}$ group. When $\mathrm{R}$ is a simple alkyl group (BBA-1 $\sim$ BBA-3), the herbicidal activity against the tested weeds at a dosage of $100 \mu \mathrm{g} \cdot \mathrm{mL}^{-1}$ is higher than those of the compounds containing benzene rings $($ BBA-4 $\sim$ BBA-6). When the phenylethylcarbonyl $\beta$-carbon atom of BBA-6 was replaced by an oxygen atom, the herbicidal activity of BBA-7 at a dosage of $100 \mu \mathrm{g} \cdot \mathrm{mL}^{-1}$ decreased sharply. These results indicated that the type of acyl group in the 5 -postion of barbituric acid played an important role in influencing herbicidal activity.

Upon analyzing the herbicidal activity of compounds BBA-7 $\sim$ BBA-16 against $B$. campestris at a dosage of 100 $\mu \mathrm{g} \cdot \mathrm{mL}^{-1}$, it was found that the herbicidal activity could be influenced by the benzene ring substituents of compound BBA-7. Among the compounds with a single substituent, those with substituent in the 4-position exhibited better herbicidal activity than compounds with a substituent in the 2- or 3-position, compounds with a chlorine atom on the benzene ring (BBA-8 $\sim$ BBA-10) displayed better herbicidal activity than those with a methyl or trifluoromethyl substituent (BBA-11 $\sim$ BBA-16). Herbicidal activity of the compounds with two chlorine atoms on the benzene ring (BBA-17 BBA-21) can be summarized as follows: BBA$18(2-\mathrm{Cl}-4-\mathrm{Cl})>$ BBA-19 $(2-\mathrm{Cl}-5-\mathrm{Cl})>$ BBA-17 $(2-\mathrm{Cl}-3-$ $\mathrm{Cl})>$ BBA-20 $(3-\mathrm{Cl}-5-\mathrm{Cl})>$ BBA-21 $(2-\mathrm{Cl}-6-\mathrm{Cl})$. The pattern demonstrates that the 2,4-disubstituted molecule was the most active and the 2,6-disubstituted one was the least. Based on the above analysis, it was concluded that introducing a halogen atom at the 2,4-position of the benzene ring of compound BBA-7 is optimal for improving the herbicidal activity of the target compounds against $B$. campestris. Our conclusion was verified by the bioassay results of compounds BBA-22 $\sim$ BBA-27. It was found that double-substituted compounds BBA-22 $\sim$ BBA-27 at the 2,4-position of the benzene ring displayed good herbicidal activity against $B$. campestris even at a dosage of 10 $\mu \mathrm{g} \cdot \mathrm{mL}^{-1}$. Noteworthy, replacing the benzene ring of compound BBA-7 with naphthalene sharply decreased the herbicidal activity of the resulting compound BBA-29. Even though two halogen atoms were introduced into naphthalene of compound BBA-29, the herbicidal activity did not improve significantly (BBA-30 and BBA-31).

To understand the herbicidal mechanism of the target compounds, the phenotypes of $A$. thaliana, treated with compound BBA-22, mesotrione, and 2,4-D, were investigated. It was found that $A$. thaliana treated with $10 \mu \mathrm{mol} / \mathrm{L}$ mesotrione exhibited bleaching symptoms, whereas $A$. thaliana treated with compound BBA-22 did not (Figure $5 \mathrm{~A}$ ), indicating that the herbicidal mode of action of compound BBA-22 is different from that of mesotrione. Interestingly, compound BBA-22 at a lower concentration (0.01 $\mu \mathrm{mol} / \mathrm{L}$ ) induced lateral root hairs formation in A. thaliana, which was consistent with the plant exposure to 2,4-D (Figure 5B). The phenotype indicates that compound BBA-22 may be an auxin-type compound. To verify the hypothesis, the effects of compound BBA-22 on the expression of the auxin-induced gene (IAA5), auxin-regulated gene (GH3.3), and auxin transport gene (AUXI) were investigated (Figure 5C) ${ }^{[49-52]}$ It was found that the expression levels of $I A A 5, G H 3.3$, and $A U X 1$ were downregulated after the treatment of $A$. thaliana with mesotrione. In contrast, upon prolonging the treatment time with compound BBA-22, the expression levels of IAA5, GH3.3, and $A U X 1$ were upregulated, and the trend was consistent with that observed for 2,4-D. The above finding confirmed that compound BBA-22 behaves as an auxin-type compound.

Furthermore, the degradation of compound BBA-22 in A. thaliana was investigated to explain why BBA-22 has a similar herbicidal mechanism to that of 2,4-D, but not mesotrione. As shown in Figure 6A, it was found that with the degradation of compound BBA-22 in A. thaliana, two new peaks were observed at 13.5 and $17.2 \mathrm{~min}$. The peak at $13.5 \mathrm{~min}$ was also observed in the spectrum of 2-(2chloro-4-fluorophenoxy) acetic acid (Figure 6B), which demonstrates that compound BBA-22 was degraded to 2-(2-chloro-4-fluorophenoxy) acetic acid in A. thaliana. The observation supports the hypothesis that the herbicidal mechanism of compound BBA-22 is similar to that of auxin herbicides. Notably, 2-(2-chloro-4-fluorophenoxy) acetic acid was completely degraded after $2.5 \mathrm{~h}$, while compound BBA-22 undergone continuous degradation to release 2-(2-chloro-4-fluorophenoxy) acetic acid. Therefore, compound BBA-22 can exert sustained herbicidal 


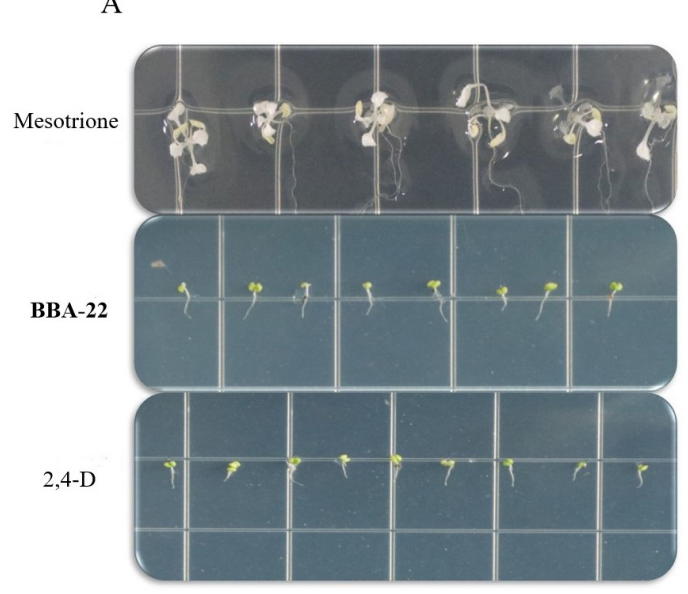

C

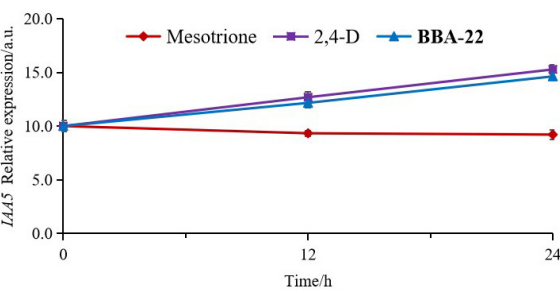

B

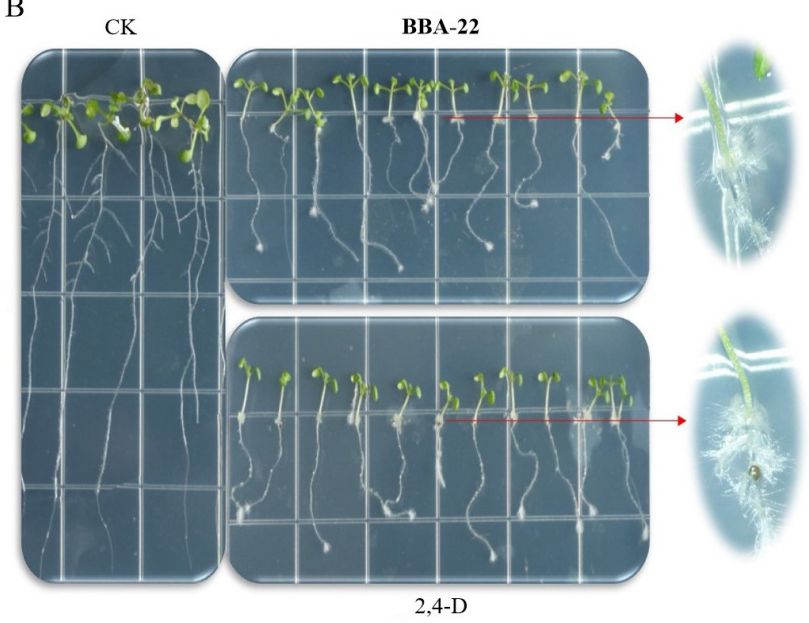

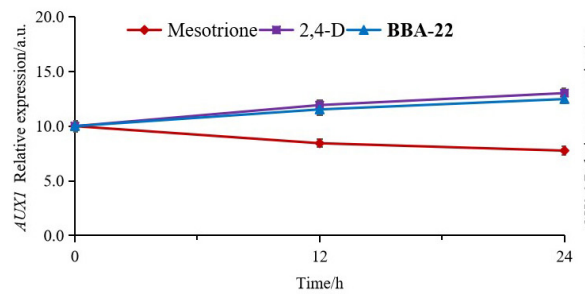

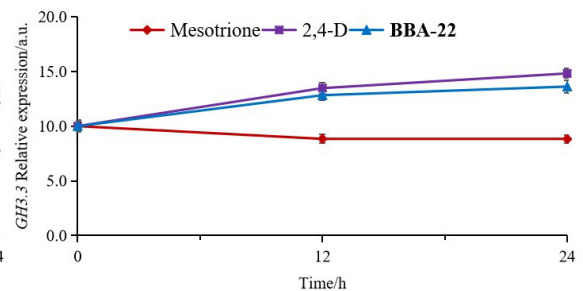

Figure 5 Photographs illustrating seedling (A) and root phenotype (B) of A. thaliana and effect of BBA-22, mesotrione, and 2,4-D on the expression levels of $I A A 5, G H 3.3$, and $A U X 1$ (C) (error bars represent standard deviation from three biological replicates)

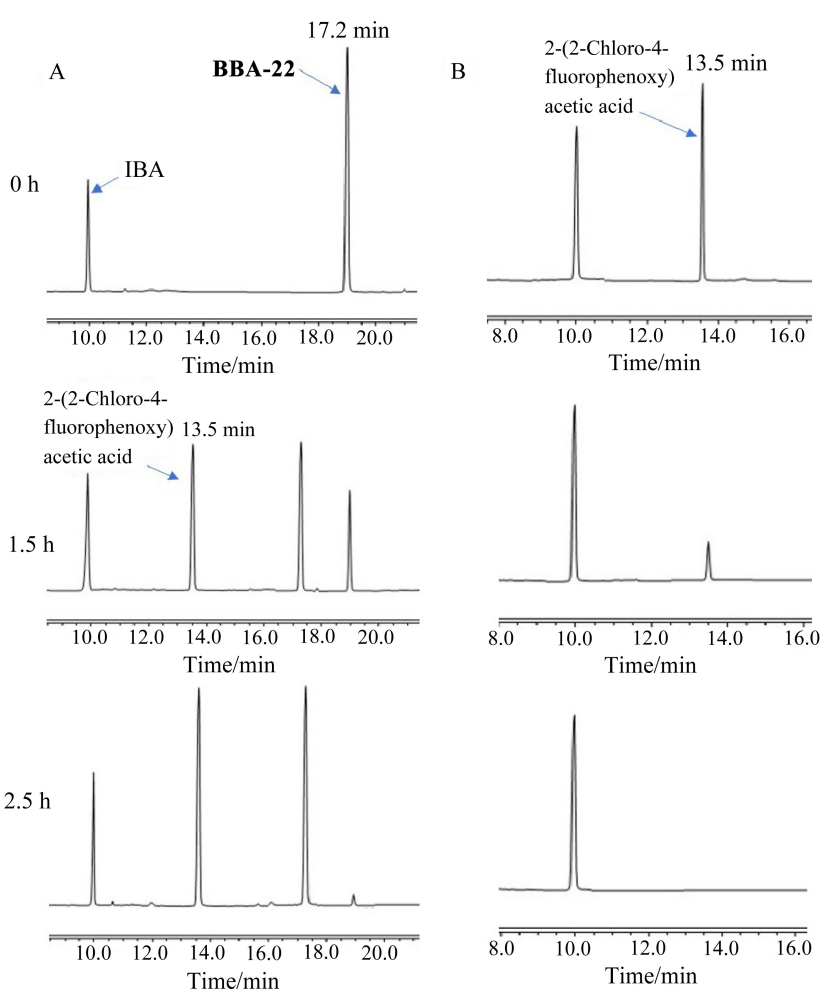

Figure 6 Degradation analysis of compound BBA-22 (A) and 2-(2-chloro-4-fluorophenoxy) acetic acid (B) in A. thaliana

activity due to the prolonged lifetime of phenoxycarboxylic acid.

\subsection{Herbicidal activity in greenhouse tests}

Based on the in vitro bioassay results, compounds BBA-22 and BBA-27 were chosen for further study, and the herbicidal activity against four species representative of monocotyledonous and dicotyledonous greenhouse plants was tested. 2,4-D was selected as the positive control. As the results shown in Table 1, it was found that compounds BBA-22 and BBA-27 showed good herbicidal activity against all tested weeds at a dosage of $1500 \mathrm{~g} \bullet \mathrm{ha}^{-1}$. When the dosage reduced from $1500 \sim 187.5 \mathrm{~g} \bullet \mathrm{ha}^{-1}$, the herbicidal activity of the tested compounds and 2,4-D reduced progressively. However, when the dosage was reduced to $187.5 \mathrm{~g} \bullet \mathrm{ha}^{-1}$, compound BBA-22 still displayed good pre-emergent herbicidal activity against B. campestris, $A$. retroflexus, and $D$. sanguinalis (better than that of 2,4-D). The promising result indicates that compound BBA-22 possesses good pre-emergent herbicidal activity that can potentially be further optimized.

\section{Conclusions}

In summary, by combining the structural features of $\beta$-triketones and barbituric acid, a series of 5-acylbarbituric acid derivatives have been designed and synthesized. The greenhouse bioassay results showed that the target compounds BBA-22 and BBA-27 possessed good preemergent herbicidal activity. In particular, compound BBA-22 displayed good pre-emergent herbicidal activity against $B$. campestris, $A$. retroflexus, and $D$. sanguinalis even at a dosage of $187.5 \mathrm{~g} \cdot \mathrm{ha}^{-1}$. By investigating the 
Table 1 Further herbicidal testing of compounds BBA-22 and BBA-27 in a greenhouse (percent inhibition) ${ }^{a}$

\begin{tabular}{|c|c|c|c|c|c|c|c|c|c|}
\hline \multirow{2}{*}{ Compd. } & \multirow{2}{*}{ Rate $/\left(\mathrm{g} \cdot \mathrm{ha}^{-1}\right)$} & \multicolumn{2}{|c|}{ B. campestris } & \multicolumn{2}{|c|}{ A. retroflexus } & \multicolumn{2}{|c|}{ E. crusgalli } & \multicolumn{2}{|c|}{ D. sanguinalis } \\
\hline & & Pre & Post & Pre & Post & Pre & Post & Pre & Post \\
\hline \multirow{4}{*}{ BBA-22 } & 1500 & 100 & 100 & 100 & 100 & 100 & 100 & 100 & 100 \\
\hline & 750 & 100 & 100 & 100 & 100 & $85.5 \pm 2.4$ & $50.5 \pm 2.0$ & $97.3 \pm 1.2$ & $55.1 \pm 2.0$ \\
\hline & 375 & $92.7 \pm 3.2$ & $53.3 \pm 3.1$ & 100 & $84.0 \pm 2.3$ & $36.6 \pm 2.7$ & 0 & $72.6 \pm 2.7$ & $17.7 \pm 1.7$ \\
\hline & 187.5 & $55.0 \pm 2.5$ & $17.4 \pm 2.2$ & $93.4 \pm 2.6$ & $58.0 \pm 2.1$ & $10.0 \pm 2.0$ & 0 & $47.4 \pm 3.0$ & 0 \\
\hline \multirow{4}{*}{ BBA-27 } & 1500 & 100 & 100 & 100 & 100 & 100 & 100 & 100 & 100 \\
\hline & 750 & $94.6 \pm 1.3$ & $52.1 \pm 3.3$ & 100 & $96.3 \pm 2.7$ & $81.7 \pm 1.6$ & $44.2 \pm 2.4$ & $81.3 \pm 2.1$ & $51.3 \pm 3.3$ \\
\hline & 375 & $82.6 \pm 2.3$ & $39.2 \pm 1.7$ & $90.0 \pm 3.3$ & $66.3 \pm 2.0$ & $37.2 \pm 3.3$ & 0 & $66.3 \pm 1.5$ & $13.4 \pm 2.0$ \\
\hline & 187.5 & $43.3 \pm 1.6$ & $12.7 \pm 2.0$ & $77.2 \pm 2.4$ & $43.3 \pm 3.1$ & 0 & 0 & $44.2 \pm 2.3$ & 0 \\
\hline \multirow{4}{*}{$2,4-\mathrm{D}$} & 1500 & 100 & 100 & 100 & 100 & 100 & 100 & 100 & 100 \\
\hline & 750 & 100 & 100 & 100 & 100 & $94.6 \pm 1.9$ & $46.6 \pm 1.7$ & 100 & $45.0 \pm 1.0$ \\
\hline & 375 & $90.1 \pm 2.1$ & 100 & 100 & 100 & $73.3 \pm 1.6$ & $21.1 \pm 2.3$ & $55.0 \pm 3.1$ & $10.5 \pm 1.3$ \\
\hline & 187.5 & $38.8 \pm 3.6$ & 100 & $91.3 \pm 1.5$ & 100 & $47.6 \pm 3.3$ & $10.0 \pm 2.0$ & $22.4 \pm 1.6$ & 0 \\
\hline
\end{tabular}

${ }^{a}$ Value represents the mean $\pm \mathrm{SD}$ of three experiments.

phenotypes of $A$. thaliana, detecting the effect on the auxin response genes, and studying the degradation of compound BBA-22, we found that BBA-22 is metabolized to form a corresponding aryloxy acetic acid in plants and, thus, has a herbicidal mechanism similar to that of auxin-type herbicides. It is worth mentioning that in our current work, the compounds generated by molecular hybridization prolong the lifetime of herbicides in plants, which may exert a sustained herbicidal effect. This is a step forward as less herbicide need be used, which would have a very important meaning in practical applications. Further studies on the structural optimization of compound BBA-22 are ongoing in our laboratory.

\section{Experimental section}

\subsection{Reagents and instruments}

Usually, chemicals and solvents (purchased from Energy Chemical and Tokyo Chemical Industry) were used as received unless otherwise stated. Melting points for target compounds were determined on a X-4 binocular microscope (Gongyi Tech. Instrument Co., Henan, China). ${ }^{1} \mathrm{H}$ NMR (400 MHz) and ${ }^{13} \mathrm{C}$ NMR $(100 \mathrm{MHz})$ were recorded with $\mathrm{CDCl}_{3}$ or DMSO- $d_{6}$ as solvent. The chemical shifts $(\delta)$ are reported relative to tetramethylsilane (TMS). High-resolution mass spectrometry was recorded using an Ionspec 7.0 $\mathrm{T}$ spectrometer (Varian, Palo Alto, CA), equipped with an ESI source. The crystal structure was determined on a Saturn 724 CCD area-detector diffractometer (Rigaku, Tokyo, Japan). Real-time PCRs was performed with a Bio-Rad real-time thermal cycling system (Bio-Rad CFX96, USA). High-performance liquid chromatography (HPLC) data were obtained on a Thermo UltiMate3000 (USA).

\subsection{Chemical synthesis procedures}

4.2.1 Synthesis of 1,3-dimethylpyrimidine-2,4,6(1H, $3 H, 5 H)$-trione (3)

1,3-Dimethylpyrimidine-2,4,6(1H,3H,5H)-trione (3) was synthesized by a previously reported method with slight modification ${ }^{[53]}$ Metal sodium $(0.5 \mathrm{~mol})$ was added gradually to $400 \mathrm{~mL}$ of absolute ethanol at room temperature, and the solution was stirred for $1 \mathrm{~h}$. Subsequently, 1,3-dimethylurea 1 (0.5 mol) and diethyl malonate 2 (0.55 mol) were slowly added, and the reaction mixture was heated to $80{ }^{\circ} \mathrm{C}$ for $12 \mathrm{~h}$. After completion of the reaction, the solvent was evaporated to one-third of the original volume under reduced pressure, $500 \mathrm{~mL}$ of water was added, and the mixture was acidified with aqueous hydrochloric acid solution $(1 \mathrm{~mol} / \mathrm{L})$ to $\mathrm{pH}=2$. The mixture was cooled to $0{ }^{\circ} \mathrm{C}$ and the product was crystallized. The residue was collected by filtration and dried under vacuum to produce a pale yellow solid 3 in $41.7 \%$ yield. m.p. 123 $125{ }^{\circ} \mathrm{C} ;{ }^{1} \mathrm{H}$ NMR $\left(500 \mathrm{MHz}, \mathrm{CDCl}_{3}\right) \delta: 3.61(\mathrm{~s}, 2 \mathrm{H}), 3.23$ $(\mathrm{s}, 6 \mathrm{H}) ;{ }^{13} \mathrm{C} \mathrm{NMR}\left(125 \mathrm{MHz}, \mathrm{CDCl}_{3}\right) \delta: 164.8,151.9,39.4$, 28.4; HRMS calcd for $\mathrm{C}_{6} \mathrm{H}_{9} \mathrm{~N}_{2} \mathrm{O}_{3}[\mathrm{M}+\mathrm{H}]^{+}$157.0608, found 157.0611 .

4.2.2 General procedure for the synthesis of aryloxyacetyl chloride derivative 9

Aryloxyacetyl chloride derivative 9 was synthesized by a previously reported method. ${ }^{[46]}$ Phenol $5(20 \mathrm{mmol})$ was dissolved in $100 \mathrm{~mL}$ of DMF, potassium carbonate $(30$ mmol) was added and the reaction mixture was heated to $50{ }^{\circ} \mathrm{C}$. Subsequently, methyl chloroacetate 6 (22 mmol) was added dropwise over $10 \mathrm{~min}$, and the suspension was stirred at $50{ }^{\circ} \mathrm{C}$ for $12 \mathrm{~h}$. After completion of the reaction, the solution was partitioned between ethyl acetate and water, and the aqueous layer was extracted three times with ethyl acetate. The combined organic layers were washed with brine, dried over anhydrous sodium sulfate, and concentrated to obtain the crude product 7 . Next, the crude product 7 was dissolved in a methanol/water $(50 \mathrm{~mL} / 5 \mathrm{~mL})$ system, and sodium hydroxide $(40 \mathrm{mmol})$ was added. The solution was heated to $70{ }^{\circ} \mathrm{C}$ and stirred for $2 \mathrm{~h}$. After completion of the reaction, the solution volume was halved. The reaction mixture was cooled to $0{ }^{\circ} \mathrm{C}$ and acidified with aqueous hydrochloric acid solution (1 $\mathrm{mol} / \mathrm{L}$ ) to $\mathrm{pH}=1$. The resulting solid was collected by filtration, washed with water, and dried under vacuum to 
afford aryloxyacetic acid 8. Aryloxyacetic acid 8 (10 $\mathrm{mmol})$ was dissolved in dichloromethane $(20 \mathrm{~mL})$, followed by the addition of oxalyl chloride $(20 \mathrm{mmol})$ and DMF (one drop). The mixture was stirred at room temperature for $12 \mathrm{~h}$ until no more gas evolved. Then, the solvent was removed by rotary evaporation to yield the aryloxyacetyl chloride derivative 9, which was used without purification.

4.2.3 General preparation of 5-acylbarbituric acid derivatives $\mathbf{B B A}-\mathbf{1} \sim \mathbf{B B A - 3 1}$

The target compounds were prepared by modifying previously reported method. ${ }^{[54]}$ 1,3-Dimethylpyrimidine2,4,6(1H,3H,5H)-trione (3) (5 mmol) was dissolved in dichloromethane $(20 \mathrm{~mL})$, followed by the addition of acetyl chloride derivative 4 or 9 (10 mmol) and triethylamine (20 mmol) at $0{ }^{\circ} \mathrm{C}$. The solution was stirred at $25{ }^{\circ} \mathrm{C}$ for $12 \mathrm{~h}$. After completion of the reaction, $20 \mathrm{~mL}$ of aqueous hydrochloric acid solution $(1 \mathrm{~mol} / \mathrm{L})$ was added. The organic layer was separated, washed with water and brine, dried over anhydrous sodium sulfate, and concentrated by rotary evaporation. The residue was scratched in ethyl acetate and petroleum ether (1/5 by volume) to yield the target compounds BBA-1 $\sim$ BBA-31.

5-(1-Hydroxyethylidene)-1,3-dimethylpyrimidine2,4,6(1H,3H,5H)-trione (BBA-1): White solid, yield 67.3\%. m.p. 97 98 ${ }^{\circ} \mathrm{C} ;{ }^{1} \mathrm{H}$ NMR (400 MHz, $\left.\mathrm{CDCl}_{3}\right) \delta$ : $3.37(\mathrm{~s}, 3 \mathrm{H}), 3.33(\mathrm{~s}, 3 \mathrm{H}), 2.72(\mathrm{~s}, 3 \mathrm{H}) ;{ }^{13} \mathrm{C}$ NMR $(100$ $\left.\mathrm{MHz}, \mathrm{CDCl}_{3}\right) \delta: 196.2,169.4,161.2,150.5,95.9,28.0$, 27.8, 24.8; HRMS calcd for $\mathrm{C}_{8} \mathrm{H}_{11} \mathrm{~N}_{2} \mathrm{O}_{4}[\mathrm{M}+\mathrm{H}]{ }^{+}$ 199.0713, found 199.0715.

5-(1-Hydroxypropylidene)-1,3-dimethylpyrimidine2,4,6(1H,3H,5H)-trione (BBA-2): White solid, yield 61.6\%. m.p. $124 \sim 125{ }^{\circ} \mathrm{C} ;{ }^{1} \mathrm{H}$ NMR (400 MHz, $\left.\mathrm{CDCl}_{3}\right) \delta$ : 3.38 (s, 3H), 3.34 (s, 3H), 3.19 (q, J=7.4 Hz, 2H), 1.25 (t, $J=7.4 \mathrm{~Hz}, 3 \mathrm{H}) ;{ }^{13} \mathrm{C}$ NMR $\left(100 \mathrm{MHz}, \mathrm{CDCl}_{3}\right) \delta: 200.7$, $169.8,160.9,150.4,95.0,30.5,28.0,27.9,9.5$; HRMS calcd for $\mathrm{C}_{9} \mathrm{H}_{13} \mathrm{~N}_{2} \mathrm{O}_{4}[\mathrm{M}+\mathrm{H}]^{+}$213.0870, found 213.0872 .

5-(1-Hydroxy-2-methylpropylidene)-1,3-dimethyl-pyrimidine-2,4,6(1H,3H,5H)-trione (BBA-3): White solid, yield 47.2\%. m.p. $93 \sim 94{ }^{\circ} \mathrm{C}$; ${ }^{1} \mathrm{H}$ NMR $(400 \mathrm{MHz}$, $\left.\mathrm{CDCl}_{3}\right) \delta: 4.36 \sim 4.18(\mathrm{~m}, 1 \mathrm{H}), 3.38(\mathrm{~s}, 3 \mathrm{H}), 3.34(\mathrm{~s}, 3 \mathrm{H})$, $1.24(\mathrm{~s}, 3 \mathrm{H}), 1.22(\mathrm{~s}, 3 \mathrm{H}) ;{ }^{13} \mathrm{C}$ NMR $\left(100 \mathrm{MHz}, \mathrm{CDCl}_{3}\right) \delta$ : 204.3, 170.1, 160.7, 150.4, 94.2, 33.5, 28.1, 27.9, 19.0; HRMS calcd for $\mathrm{C}_{10} \mathrm{H}_{15} \mathrm{~N}_{2} \mathrm{O}_{4}[\mathrm{M}+\mathrm{H}]^{+}$227.1026, found 227.1027.

5-(Hydroxy(phenyl)methylene)-1,3-dimethylpyrimidine2,4,6(1H,3H,5H)-trione (BBA-4): White solid, yield 53.0\%. m.p. 102 104 ${ }^{\circ} \mathrm{C} ;{ }^{1} \mathrm{H}$ NMR $\left(400 \mathrm{MHz}, \mathrm{CDCl}_{3}\right) \delta$ : $7.60 \sim 7.52(\mathrm{~m}, 3 \mathrm{H}), 7.48 \sim 7.44(\mathrm{~m}, 2 \mathrm{H}), 3.44(\mathrm{~s}, 3 \mathrm{H})$, $3.28(\mathrm{~s}, 3 \mathrm{H}) ;{ }^{13} \mathrm{C} \mathrm{NMR}\left(100 \mathrm{MHz}, \mathrm{CDCl}_{3}\right) \delta: 191.7,170.3$, 160.0, 150.5, 134.7, 132.0, 128.4, 127.8, 95.2, 28.3, 28.1; HRMS calcd for $\mathrm{C}_{13} \mathrm{H}_{13} \mathrm{~N}_{2} \mathrm{O}_{4}[\mathrm{M}+\mathrm{H}]^{+}$261.0870, found 261.0872 .

5-(1-Hydroxy-2-phenylethylidene)-1,3-dimethylpyrimidine-2,4,6(1H,3H,5H)-trione (BBA-5): White solid, yield 61.0\%. m.p. 92 $94{ }^{\circ} \mathrm{C}$; ${ }^{1} \mathrm{H}$ NMR (400 MHz, $\left.\mathrm{CDCl}_{3}\right) \delta$ :
$7.54 \sim 7.19(\mathrm{~m}, 5 \mathrm{H}), 4.51(\mathrm{~s}, 2 \mathrm{H}), 3.35(\mathrm{~s}, 6 \mathrm{H}) ;{ }^{13} \mathrm{C} \mathrm{NMR}$ $\left(100 \mathrm{MHz}, \mathrm{CDCl}_{3}\right) \delta: 196.4,169.9,160.9,150.3,134.4$, $129.7,128.7,127.4,95.3,41.9,28.2$, 28.0; HRMS calcd for $\mathrm{C}_{14} \mathrm{H}_{15} \mathrm{~N}_{2} \mathrm{O}_{4}[\mathrm{M}+\mathrm{H}]^{+}$275.1026, found 275.1028.

5-(1-Hydroxy-3-phenylpropylidene)-1,3-dimethylpyrimidine-2,4,6(1H,3H,5H)-trione (BBA-6): White solid, yield 69.5\%. m.p. $93 \sim 94{ }^{\circ} \mathrm{C} ;{ }^{1} \mathrm{H}$ NMR (400 MHz, $\left.\mathrm{CDCl}_{3}\right) \delta: 7.33 \sim 7.27(\mathrm{~m}, 4 \mathrm{H}), 7.25 \sim 7.17(\mathrm{~m}, 1 \mathrm{H}), 3.47$ $(\mathrm{t}, J=8.0 \mathrm{~Hz}, 2 \mathrm{H}), 3.37(\mathrm{~s}, 3 \mathrm{H}), 3.34(\mathrm{~s}, 3 \mathrm{H}), 3.00(\mathrm{t}, J=$ $8.0 \mathrm{~Hz}, 2 \mathrm{H}) ;{ }^{13} \mathrm{C}$ NMR $\left(100 \mathrm{MHz}, \mathrm{CDCl}_{3}\right) \delta: 198.4,169.8$, $160.8,150.4,140.3,128.5,128.5,126.4,95.4,38.7,31.5$, 28.1, 27.9; HRMS calcd for $\mathrm{C}_{15} \mathrm{H}_{17} \mathrm{~N}_{2} \mathrm{O}_{4}[\mathrm{M}+\mathrm{H}]{ }^{+}$ 289.1183 , found 289.1185 .

5-(1-Hydroxy-2-phenoxyethylidene)-1,3-dimethylpyrimidine-2,4,6(1H,3H,5H)-trione (BBA-7): White solid, yield 63.3\%. m.p. 203 $204{ }^{\circ} \mathrm{C}$; ${ }^{1} \mathrm{H}$ NMR $(400 \mathrm{MHz}$, $\left.\mathrm{CDCl}_{3}\right) \delta: 7.35 \sim 7.28(\mathrm{~m}, 2 \mathrm{H}), 7.01(\mathrm{t}, J=7.4 \mathrm{~Hz}, 1 \mathrm{H})$, $6.98 \sim 6.93(\mathrm{~m}, 2 \mathrm{H}), 5.51(\mathrm{~s}, 2 \mathrm{H}), 3.39(\mathrm{~s}, 6 \mathrm{H}) ;{ }^{13} \mathrm{C} \mathrm{NMR}$ $\left(100 \mathrm{MHz}, \mathrm{CDCl}_{3}\right) \delta: 194.6,169.6,160.8,157.9,150.2$, 129.6, 121.8, 114.6, 94.0, 68.5, 28.0; HRMS calcd for $\mathrm{C}_{14} \mathrm{H}_{15} \mathrm{~N}_{2} \mathrm{O}_{5}[\mathrm{M}+\mathrm{H}]^{+}$291.0975, found 291.0976.

5-(2-(2-Chlorophenoxy)-1-hydroxyethylidene)-1,3dimethylpyrimidine-2,4,6(1H,3H,5H)-trione (BBA-8): White solid, yield $47.1 \%$. m.p. $210 \sim 211{ }^{\circ} \mathrm{C}$; ${ }^{1} \mathrm{H}$ NMR $\left(400 \mathrm{MHz}, \mathrm{CDCl}_{3}\right) \delta: 7.43(\mathrm{~d}, J=7.4 \mathrm{~Hz}, 1 \mathrm{H}), 7.21(\mathrm{t}, J=$ $6.9 \mathrm{~Hz}, 1 \mathrm{H}), 6.98(\mathrm{t}, J=6.0 \mathrm{~Hz}, 1 \mathrm{H}), 6.90(\mathrm{~d}, J=7.5 \mathrm{~Hz}$, $1 \mathrm{H}), 5.60(\mathrm{~s}, 2 \mathrm{H}), 3.43(\mathrm{~s}, 3 \mathrm{H}), 3.38(\mathrm{~s}, 3 \mathrm{H}) ;{ }^{13} \mathrm{C} \mathrm{NMR}$ $\left(100 \mathrm{MHz}, \mathrm{CDCl}_{3}\right) \delta: 193.8,169.5,160.7,153.5,150.1$, 130.7, 127.7, 123.1, 122.5, 113.7, 93.9, 69.3, 28.1, 28.0; HRMS calcd for $\mathrm{C}_{14} \mathrm{H}_{14} \mathrm{ClN}_{2} \mathrm{O}_{5}[\mathrm{M}+\mathrm{H}]^{+} 325.0586$, found 325.0588 .

5-(2-(3-Chlorophenoxy)-1-hydroxyethylidene)-1,3dimethylpyrimidine-2,4,6(1H,3H,5H)-trione (BBA-9): White solid, yield $48.0 \%$. m.p. $198 \sim 199{ }^{\circ} \mathrm{C}$; ${ }^{1} \mathrm{H}$ NMR $\left(400 \mathrm{MHz}, \mathrm{CDCl}_{3}\right) \delta: 7.24(\mathrm{t}, J=8.0 \mathrm{~Hz}, 1 \mathrm{H}), 7.01(\mathrm{~d}, J=$ $7.9 \mathrm{~Hz}, 1 \mathrm{H}), 6.97(\mathrm{~s}, 1 \mathrm{H}), 6.87$ (d, $J=8.2 \mathrm{~Hz}, 1 \mathrm{H}), 5.51(\mathrm{~s}$, $2 \mathrm{H}), 3.43(\mathrm{~s}, 3 \mathrm{H}), 3.39(\mathrm{~s}, 3 \mathrm{H}) ;{ }^{13} \mathrm{C} \mathrm{NMR}(100 \mathrm{MHz}$, $\left.\mathrm{CDCl}_{3}\right) \delta: 194.0,169.6,160.7,158.6,150.1,135.1,130.4$, 122.0, 115.2, 113.1, 94.0, 68.6, 28.1, 28.0; HRMS calcd for $\mathrm{C}_{14} \mathrm{H}_{14} \mathrm{ClN}_{2} \mathrm{O}_{5}[\mathrm{M}+\mathrm{H}]^{+}$325.0586, found 325.0588 .

5-(2-(4-Chlorophenoxy)-1-hydroxyethylidene)-1,3dimethylpyrimidine-2,4,6(1H,3H,5H)-trione (BBA-10): White solid, yield 53.6\%. m.p. $172 \sim 174{ }^{\circ} \mathrm{C} ;{ }^{1} \mathrm{H}$ NMR $\left(400 \mathrm{MHz}, \mathrm{CDCl}_{3}\right) \delta: 7.26(\mathrm{~d}, J=7.7 \mathrm{~Hz}, 2 \mathrm{H}), 6.89(\mathrm{~d}, J=$ $7.7 \mathrm{~Hz}, 2 \mathrm{H}), 5.48$ (s, 2H), 3.42 (s, 3H), 3.37 (s, 3H); ${ }^{13} \mathrm{C}$ NMR $\left(100 \mathrm{MHz}, \mathrm{CDCl}_{3}\right) \delta: 194.1,169.6,160.7,156.5$, $150.1,129.5,126.7,116.0,94.0,68.8,28.1,28.0$; HRMS calcd for $\mathrm{C}_{14} \mathrm{H}_{14} \mathrm{ClN}_{2} \mathrm{O}_{5}[\mathrm{M}+\mathrm{H}]^{+}$325.0586, found 325.0588 .

5-(1-Hydroxy-2-(o-tolyloxy)ethylidene)-1,3-dimethylpyrimidine-2,4,6(1H,3H,5H)-trione (BBA-11): White solid, yield 51.0\%. m.p. 213 $214{ }^{\circ} \mathrm{C} ;{ }^{1} \mathrm{H}$ NMR (400 MHz, $\left.\mathrm{CDCl}_{3}\right) \delta: 7.18(\mathrm{~d}, J=7.3 \mathrm{~Hz}, 1 \mathrm{H}), 7.12(\mathrm{t}, J=7.6 \mathrm{~Hz}, 1 \mathrm{H})$, $6.91(\mathrm{t}, J=7.3 \mathrm{~Hz}, 1 \mathrm{H}), 6.74(\mathrm{~d}, J=8.1 \mathrm{~Hz}, 1 \mathrm{H}), 5.53(\mathrm{~s}$, $2 \mathrm{H}), 3.40(\mathrm{~s}, 3 \mathrm{H}), 3.36(\mathrm{~s}, 3 \mathrm{H}), 2.33(\mathrm{~s}, 3 \mathrm{H}) ;{ }^{13} \mathrm{C} \mathrm{NMR}$ $\left(100 \mathrm{MHz}, \mathrm{CDCl}_{3}\right) \delta: 194.9,169.6,160.8,156.1,150.2$, $131.1,127.2,126.8,121.4,111.2,94.0,68.7,28.1,28.0$, 
16.2; HRMS calcd for $\mathrm{C}_{15} \mathrm{H}_{17} \mathrm{~N}_{2} \mathrm{O}_{5}[\mathrm{M}+\mathrm{H}]^{+}$305.1132, found 305.1133 .

5-(1-Hydroxy-2-( $m$-tolyloxy)ethylidene)-1,3-dimethylpyrimidine-2,4,6(1H,3H,5H)-trione (BBA-12): White solid, yield 55.3\%. m.p. $185 \sim 187{ }^{\circ} \mathrm{C} ;{ }^{1} \mathrm{H}$ NMR $(400 \mathrm{MHz}$, $\left.\mathrm{CDCl}_{3}\right) \delta: 7.18(\mathrm{t}, J=7.8 \mathrm{~Hz}, 1 \mathrm{H}), 6.82(\mathrm{~d}, J=7.5 \mathrm{~Hz}, 1 \mathrm{H})$, $6.78(\mathrm{~s}, 1 \mathrm{H}), 6.75(\mathrm{~d}, J=8.2 \mathrm{~Hz}, 1 \mathrm{H}), 5.49(\mathrm{~s}, 2 \mathrm{H}), 3.41$ (s, $3 \mathrm{H}), 3.36(\mathrm{~s}, 3 \mathrm{H}), 2.33(\mathrm{~s}, 3 \mathrm{H}) ;{ }^{13} \mathrm{C} \mathrm{NMR}(100 \mathrm{MHz}$, $\left.\mathrm{CDCl}_{3}\right) \delta: 194.8,169.6,160.8,157.8,150.2,139.8$ 129.4, 122.6, 115.4, 111.4, 93.9, 68.4, 28.1, 28.0, 21.6; HRMS calcd for $\mathrm{C}_{15} \mathrm{H}_{17} \mathrm{~N}_{2} \mathrm{O}_{5}[\mathrm{M}+\mathrm{H}]{ }^{+}$305.1132, found 305.1134 .

5-(1-Hydroxy-2-( $p$-tolyloxy)ethylidene)-1,3-dimethylpyrimidine-2,4,6(1H,3H,5H)-trione (BBA-13): White solid, yield 50.6\%. m.p. $183 \sim 185{ }^{\circ} \mathrm{C} ;{ }^{1} \mathrm{H}$ NMR $(400 \mathrm{MHz}$, $\left.\mathrm{CDCl}_{3}\right) \delta: 7.10(\mathrm{~d}, J=8.2 \mathrm{~Hz}, 2 \mathrm{H}), 6.85(\mathrm{~d}, J=8.0 \mathrm{~Hz}$, 2H), 5.48 (s, 2H), 3.40 (s, 3H), 3.36 (s, 3H), 2.29 (s, 3H); ${ }^{13} \mathrm{C} \mathrm{NMR}\left(100 \mathrm{MHz}, \mathrm{CDCl}_{3}\right) \delta: 194.9,169.6,160.8,155.7$, $150.2,131.1,130.1,114.4,94.0,68.7,28.1,28.0,20.5$; HRMS calcd for $\mathrm{C}_{15} \mathrm{H}_{17} \mathrm{~N}_{2} \mathrm{O}_{5}[\mathrm{M}+\mathrm{H}]^{+}$305.1132, found 305.1134 .

5-(1-Hydroxy-2-(2-(trifluoromethyl)phenoxy)ethylidene)-1,3-dimethylpyrimidine-2,4,6(1H,3H,5H)-trione (BBA-14): White solid, yield 45.3\%. m.p. $211 \sim 212{ }^{\circ} \mathrm{C}$; ${ }^{1} \mathrm{H}$ NMR $\left(400 \mathrm{MHz}, \mathrm{CDCl}_{3}\right) \delta: 7.63(\mathrm{dd}, J=7.7,0.8 \mathrm{~Hz}$, $1 \mathrm{H}), 7.51 \sim 7.41(\mathrm{~m}, 1 \mathrm{H}), 7.07(\mathrm{t}, J=7.6 \mathrm{~Hz}, 1 \mathrm{H}), 6.91(\mathrm{~d}$, $J=8.4 \mathrm{~Hz}, 1 \mathrm{H}), 5.60$ (s, 2H), 3.41 (s, 3H), 3.37 (s, 3H); ${ }^{13} \mathrm{C}$ NMR (100 MHz, $\left.\mathrm{CDCl}_{3}\right) \delta: 193.5,169.5,160.8,155.8$, $150.1,133.2,127.44$ (q, $J=5.1 \mathrm{~Hz}$ ), 123.5 (q, $J=272.5$ $\mathrm{Hz}), 121.1,119.17$ (q, $J=31.2 \mathrm{~Hz}$ ), 112.8, 94.0, 68.8, 28.1, 28.0; HRMS calcd for $\mathrm{C}_{15} \mathrm{H}_{14} \mathrm{~F}_{3} \mathrm{~N}_{2} \mathrm{O}_{5}[\mathrm{M}+\mathrm{H}]^{+} 359.0849$, found 359.0852 .

5-(1-Hydroxy-2-(3-(trifluoromethyl)phenoxy)ethylidene)-1,3-dimethylpyrimidine-2,4,6(1H,3H,5H)-trione (BBA-15): White solid, yield 47.5\%. m.p. $165 \sim 166{ }^{\circ} \mathrm{C}$; ${ }^{1} \mathrm{H}$ NMR $\left(400 \mathrm{MHz}, \mathrm{CDCl}_{3}\right) \delta: 7.42(\mathrm{t}, J=8.0 \mathrm{~Hz}, 1 \mathrm{H})$, $7.30 \sim 7.24(\mathrm{~m}, 1 \mathrm{H}), 7.19(\mathrm{~s}, 1 \mathrm{H}), 7.12(\mathrm{dd}, J=8.3,2.4 \mathrm{~Hz}$, 1H), $5.54(\mathrm{~s}, 2 \mathrm{H}), 3.42(\mathrm{~s}, 3 \mathrm{H}), 3.37(\mathrm{~s}, 3 \mathrm{H}) ;{ }^{13} \mathrm{C} \mathrm{NMR}$ $\left(100 \mathrm{MHz}, \mathrm{CDCl}_{3}\right) \delta: 193.8,169.6,160.8,158.0,150.1$, 132.0 (q, $J=32.6 \mathrm{~Hz}), 130.2,123.8$ (q, $J=272.5 \mathrm{~Hz})$, $118.5(\mathrm{q}, J=3.7 \mathrm{~Hz}), 117.9,111.8(\mathrm{q}, J=3.8 \mathrm{~Hz}), 94.0$, 68.7, 28.1, 28.0; HRMS calcd for $\mathrm{C}_{15} \mathrm{H}_{14} \mathrm{~F}_{3} \mathrm{~N}_{2} \mathrm{O}_{5}[\mathrm{M}+\mathrm{H}]^{+}$ 359.0849 , found 359.0852 .

5-(1-Hydroxy-2-(4-(trifluoromethyl)phenoxy)ethylidene)-1,3-dimethylpyrimidine-2,4,6(1H,3H,5H)-trione (BBA-16): White solid, yield 40.1\%. m.p. $175 \sim 176{ }^{\circ} \mathrm{C}$; ${ }^{1} \mathrm{H} \mathrm{NMR}\left(400 \mathrm{MHz}, \mathrm{CDCl}_{3}\right) \delta: 7.57(\mathrm{~d}, J=8.6 \mathrm{~Hz}, 2 \mathrm{H})$, 7.02 (d, $J=8.6 \mathrm{~Hz}, 2 \mathrm{H}), 5.55$ (s, 2H), 3.42 (s, 3H), 3.37 (s, $3 \mathrm{H}) ;{ }^{13} \mathrm{C}$ NMR (100 MHz, $\left.\mathrm{CDCl}_{3}\right) \delta: 193.7,169.6,160.8$, $160.3,150.1,127.1$ (q, $J=3.8 \mathrm{~Hz}), 124.2$ (q, $J=272.7 \mathrm{~Hz}$ ), 123.9 (q, $J=32.8 \mathrm{~Hz}$ ), 114.6, 94.0, 68.5, 28.2, 28.0; HRMS calcd for $\mathrm{C}_{15} \mathrm{H}_{14} \mathrm{~F}_{3} \mathrm{~N}_{2} \mathrm{O}_{5}[\mathrm{M}+\mathrm{H}]^{+} 359.0849$, found 359.0852 .

5-(2-(2,3-Dichlorophenoxy)-1-hydroxyethylidene)-1,3dimethylpyrimidine-2,4,6(1H,3H,5H)-trione

(BBA-17): White solid, yield 55.0\%. m.p. 201 203 ${ }^{\circ} \mathrm{C}$; ${ }^{1} \mathrm{H}$ NMR $\left(400 \mathrm{MHz}, \mathrm{CDCl}_{3}\right) \delta: 7.19 \sim 7.14(\mathrm{~m}, 2 \mathrm{H}), 6.79 \sim 6.77(\mathrm{~m}$,
$1 \mathrm{H}), 5.60(\mathrm{~s}, 2 \mathrm{H}), 3.43(\mathrm{~s}, 3 \mathrm{H}), 3.38(\mathrm{~s}, 3 \mathrm{H}) ;{ }^{13} \mathrm{C} \mathrm{NMR}$ $\left(100 \mathrm{MHz}, \mathrm{CDCl}_{3}\right) \delta: 193.3,169.6,160.7,154.9,150.1$, 134.3, 127.3, 123.8, 123.4, 111.5, 93.9, 69.5, 28.1, 28.0; HRMS calcd for $\mathrm{C}_{14} \mathrm{H}_{13} \mathrm{Cl}_{2} \mathrm{~N}_{2} \mathrm{O}_{5}[\mathrm{M}+\mathrm{H}]^{+}$359.0196, found 359.0199 .

5-(2-(2,4-Dichlorophenoxy)-1-hydroxyethylidene)-1,3dimethylpyrimidine-2,4,6(1H,3H,5H)-trionee (BBA-18): White solid, yield 59.0\%. m.p. 193 $194{ }^{\circ} \mathrm{C}$; ${ }^{1} \mathrm{H}$ NMR $\left(400 \mathrm{MHz}, \mathrm{CDCl}_{3}\right) \delta: 7.42(\mathrm{~s}, 1 \mathrm{H}), 7.16(\mathrm{~d}, J=8.7 \mathrm{~Hz}$, $1 \mathrm{H}), 6.81(\mathrm{~d}, J=8.8 \mathrm{~Hz}, 1 \mathrm{H}), 5.55(\mathrm{~s}, 2 \mathrm{H}), 3.41(\mathrm{~s}, 3 \mathrm{H})$, $3.36(\mathrm{~s}, 3 \mathrm{H}) ;{ }^{13} \mathrm{C}$ NMR $\left(100 \mathrm{MHz}, \mathrm{CDCl}_{3}\right) \delta: 193.4,169.9$, $160.7,152.5,150.1,130.4,127.6127 .0,124.1,114.5,93.9$, 69.6, 28.1, 28.0; HRMS calcd for $\mathrm{C}_{14} \mathrm{H}_{13} \mathrm{Cl}_{2} \mathrm{~N}_{2} \mathrm{O}_{5}[\mathrm{M}+\mathrm{H}]^{+}$ 359.0196 , found 359.0199 .

5-(2-(2,5-Dichlorophenoxy)-1-hydroxyethylidene)-1,3dimethylpyrimidine-2,4,6(1H,3H,5H)-trione (BBA-19): White solid, yield $48.2 \%$. m.p. $185 \sim 187{ }^{\circ} \mathrm{C}$; ${ }^{1} \mathrm{H}$ NMR $\left(400 \mathrm{MHz}, \mathrm{CDCl}_{3}\right) \delta: 7.34(\mathrm{dd}, J=8.4,0.9 \mathrm{~Hz}, 1 \mathrm{H}), 6.96$ $(\mathrm{d}, J=8.5 \mathrm{~Hz}, 1 \mathrm{H}), 6.87(\mathrm{~s}, 1 \mathrm{H}), 5.57(\mathrm{~s}, 2 \mathrm{H}), 3.43(\mathrm{~s}, 3 \mathrm{H})$, $3.38(\mathrm{~s}, 3 \mathrm{H}) ;{ }^{13} \mathrm{C}$ NMR (100 MHz, $\left.\mathrm{CDCl}_{3}\right) \delta: 193.1,169.6$, $160.7,154,0,150.0,133.1,131.2,122.5,121.6,114.1$, 94.0, 69.4, 28.1, 28.0; HRMS calcd for $\mathrm{C}_{14} \mathrm{H}_{13} \mathrm{Cl}_{2} \mathrm{~N}_{2} \mathrm{O}_{5}$ $[\mathrm{M}+\mathrm{H}]^{+}$359.0196, found 359.0198.

5-(2-(3,5-Dichlorophenoxy)-1-hydroxyethylidene)-1,3dimethylpyrimidine-2,4,6(1H,3H,5H)-trione (BBA-20): White solid, yield 51.7\%. m.p. $196 \sim 197{ }^{\circ} \mathrm{C} ;{ }^{1} \mathrm{H}$ NMR $\left(400 \mathrm{MHz}, \mathrm{CDCl}_{3}\right) \delta: 7.01(\mathrm{~s}, 1 \mathrm{H}), 6.85(\mathrm{~s}, 1 \mathrm{H}), 6.84(\mathrm{~s}$, 1H), $5.47(\mathrm{~s}, 2 \mathrm{H}), 3.42(\mathrm{~s}, 3 \mathrm{H}), 3.37(\mathrm{~s}, 3 \mathrm{H}) ;{ }^{13} \mathrm{C} \mathrm{NMR}$ $\left(100 \mathrm{MHz}, \mathrm{CDCl}_{3}\right) \delta: 193.4,169.6,160.7,158.9,150.0$, 135.6, 122.2, 113.8, 94.0, 68.8, 28.2, 28.0; HRMS calcd for $\mathrm{C}_{14} \mathrm{H}_{13} \mathrm{Cl}_{2} \mathrm{~N}_{2} \mathrm{O}_{5}[\mathrm{M}+\mathrm{H}]^{+}$359.0196, found 359.0199.

5-(2-(2,6-Dichlorophenoxy)-1-hydroxyethylidene)-1,3dimethylpyrimidine-2,4,6(1H,3H,5H)-trione (BBA-21): White solid, yield 44.6\%. m.p. $196 \sim 198{ }^{\circ} \mathrm{C} ;{ }^{1} \mathrm{H}$ NMR $\left(400 \mathrm{MHz}, \mathrm{CDCl}_{3}\right) \delta: 7.32(\mathrm{~d}, J=8.1 \mathrm{~Hz}, 2 \mathrm{H}), 7.10 \sim 7.01$ (t, $J=8.0 \mathrm{~Hz}, 1 \mathrm{H}), 5.47(\mathrm{~s}, 2 \mathrm{H}), 3.43(\mathrm{~s}, 3 \mathrm{H}), 3.31(\mathrm{~s}, 3 \mathrm{H})$; ${ }^{13} \mathrm{C}$ NMR $\left(100 \mathrm{MHz}, \mathrm{CDCl}_{3}\right) \delta: 193.3,169.6,160.6,150.5$, 150.2, 129.4, 129.1, 126.0, 93.6, 72.6, 28.1, 27.9; HRMS calcd for $\mathrm{C}_{14} \mathrm{H}_{13} \mathrm{Cl}_{2} \mathrm{~N}_{2} \mathrm{O}_{5}[\mathrm{M}+\mathrm{H}]^{+}$359.0196, found 359.0198 .

5-(2-(2-Chloro-4-fluorophenoxy)-1-hydroxyethylidene)1,3-dimethylpyrimidine-2,4,6(1H,3H,5H)-trione (BBA22): White solid, yield 63.2\%. m.p. $198 \sim 199{ }^{\circ} \mathrm{C} ;{ }^{1} \mathrm{H}$ NMR $\left(400 \mathrm{MHz}, \mathrm{CDCl}_{3}\right) \delta: 7.18(\mathrm{dd}, J=8.0,2.9 \mathrm{~Hz}, 1 \mathrm{H})$, $6.95 \sim 6.83(\mathrm{~m}, 2 \mathrm{H}), 5.54(\mathrm{~s}, 2 \mathrm{H}), 3.42(\mathrm{~s}, 3 \mathrm{H}), 3.36(\mathrm{~s}$, $3 \mathrm{H}) ;{ }^{13} \mathrm{C} \mathrm{NMR}\left(100 \mathrm{MHz}, \mathrm{CDCl}_{3}\right) \delta: 193.7,169.6,160.7$, $157.2(\mathrm{~d}, J=243.8 \mathrm{~Hz}), 150.2(\mathrm{~d}, J=2.9 \mathrm{~Hz}), 150.1,124.0$ (d, $J=10.6 \mathrm{~Hz}), 118.0$ (d, $J=26.1 \mathrm{~Hz}), 114.9$ (d, $J=8.9$ Hz), 114.1 (d, $J=22.8 \mathrm{~Hz}$ ), 93.9, 70.1, 28.1, 28.0; HRMS calcd. for $\mathrm{C}_{14} \mathrm{H}_{13} \mathrm{ClFN}_{2} \mathrm{O}_{5}[\mathrm{M}+\mathrm{H}]^{+}$343.0492, found 343.0494 .

5-(2-(4-Chloro-2-methylphenoxy)-1-hydroxyethylidene)-1,3-dimethylpyrimidine-2,4,6(1H,3H,5H)-trione (BBA-23): White solid, yield 50.6\%. m.p. 219 220 ${ }^{\circ} \mathrm{C}$; ${ }^{1} \mathrm{H}$ NMR (400 MHz, $\left.\mathrm{CDCl}_{3}\right) \delta: 7.16(\mathrm{~s}, 1 \mathrm{H}), 7.07$ (d, $J=$ $8.3 \mathrm{~Hz}, 1 \mathrm{H}), 6.66(\mathrm{~d}, J=8.6 \mathrm{~Hz}, 1 \mathrm{H}), 5.50(\mathrm{~s}, 2 \mathrm{H}), 3.41(\mathrm{~s}$, $3 \mathrm{H}), 3.36(\mathrm{~s}, 3 \mathrm{H}), 2.30(\mathrm{~s}, 3 \mathrm{H}) ;{ }^{13} \mathrm{C} \mathrm{NMR}(100 \mathrm{MHz}$, 
$\left.\mathrm{CDCl}_{3}\right) \delta: 194.5,169.6,160.8,154.7,150.2,130.9,129.1$, $126.3,126.2,112.3,94.0,68.9,28.1,28.0,16.2$; HRMS calcd for $\mathrm{C}_{15} \mathrm{H}_{16} \mathrm{ClN}_{2} \mathrm{O}_{5}[\mathrm{M}+\mathrm{H}]^{+}$339.0742, found 339.0744 .

5-(2-(2,4-Dimethylphenoxy)-1-hydroxyethylidene)-1,3dimethylpyrimidine-2,4,6(1H,3H,5H)-trione (BBA-24): White solid, yield 48.3\%. m.p. 222 224 ${ }^{\circ} \mathrm{C} ;{ }^{1} \mathrm{H}$ NMR $\left(400 \mathrm{MHz}, \mathrm{CDCl}_{3}\right) \delta: 6.99(\mathrm{~s}, 1 \mathrm{H}), 6.91(\mathrm{~d}, J=8.2 \mathrm{~Hz}$, $1 \mathrm{H}), 6.64(\mathrm{~d}, J=8.2 \mathrm{~Hz}, 1 \mathrm{H}), 5.50(\mathrm{~s}, 2 \mathrm{H}), 3.40(\mathrm{~s}, 3 \mathrm{H})$, $3.36(\mathrm{~s}, 3 \mathrm{H}), 2.29(\mathrm{~s}, 3 \mathrm{H}), 2.26(\mathrm{~s}, 3 \mathrm{H}) ;{ }^{13} \mathrm{C} \mathrm{NMR}(100$ $\left.\mathrm{MHz}, \mathrm{CDCl}_{3}\right) \delta: 195.2,169.6,160.8,154.0,150.3,131.9$, $130.7,126.9,126.9,111.2,94.068 .9,28.1,28.0,20.5$, 16.2; HRMS calcd for $\mathrm{C}_{16} \mathrm{H}_{19} \mathrm{ClN}_{2} \mathrm{O}_{5}[\mathrm{M}+\mathrm{H}]^{+} 319.1288$, found 319.1291 .

5-(2-(4-Fluoro-2-methylphenoxy)-1-hydroxyethylidene)-1,3-dimethylpyrimidine-2,4,6(1H,3H,5H)-trione (BBA-25): White solid, yield 44.2\%. m.p. 220 $221{ }^{\circ} \mathrm{C}$; ${ }^{1} \mathrm{H}$ NMR $\left(400 \mathrm{MHz}, \mathrm{CDCl}_{3}\right) \delta: 6.90(\mathrm{dd}, J=8.9,3.0 \mathrm{~Hz}$, $1 \mathrm{H}), 6.80(\mathrm{td}, J=8.5,3.1 \mathrm{~Hz}, 1 \mathrm{H}), 6.69(\mathrm{dd}, J=8.9,4.5$ $\mathrm{Hz}, 1 \mathrm{H}), 5.48(\mathrm{~s}, 2 \mathrm{H}), 3.41(\mathrm{~s}, 3 \mathrm{H}), 3.36(\mathrm{~s}, 3 \mathrm{H}), 2.31(\mathrm{~s}$, $3 \mathrm{H}) ;{ }^{13} \mathrm{C} \mathrm{NMR}\left(100 \mathrm{MHz}, \mathrm{CDCl}_{3}\right) \delta: 194.8,169.6,169.6$, $160.8,157.4(\mathrm{~d}, J=239.1 \mathrm{~Hz}), 152.2(\mathrm{~d}, J=2.2 \mathrm{~Hz}), 150.2$, 129.3 (d, $J=7.7 \mathrm{~Hz}), 117.8$ (d, $J=22.9 \mathrm{~Hz}), 112.5$ (d, $J=$ 14.1 Hz), 112.4, 94.0, 69.4, 28.1, 28.0, 16.4; HRMS calcd for $\mathrm{C}_{15} \mathrm{H}_{16} \mathrm{FN}_{2} \mathrm{O}_{5}[\mathrm{M}+\mathrm{H}]^{+}$323.1038, found 323.1040.

5-(2-(2-Bromo-4-chlorophenoxy)-1-hydroxyethylidene)1,3-dimethylpyrimidine-2,4,6(1H,3H,5H)-trione (BBA26): White solid, yield 50.5\%. m.p. $199 \sim 201{ }^{\circ} \mathrm{C} ;{ }^{1} \mathrm{H}$ NMR (400 MHz, $\left.\mathrm{CDCl}_{3}\right) \delta: 7.58(\mathrm{~d}, J=2.5 \mathrm{~Hz}, 1 \mathrm{H}), 7.21$ (dd, $J=8.8,2.5 \mathrm{~Hz}, 1 \mathrm{H}), 6.77$ (d, $J=8.8 \mathrm{~Hz}, 1 \mathrm{H}), 5.55$ (s, 2H), $3.42(\mathrm{~s}, 3 \mathrm{H}), 3.36(\mathrm{~s}, 3 \mathrm{H}) ;{ }^{13} \mathrm{C} \mathrm{NMR}(100 \mathrm{MHz}$, $\left.\mathrm{CDCl}_{3}\right) \delta: 193.4,169.6,160.7,153.3,150.1,133.3,128.3$, 127.3, 114.1, 112.8, 93.9, 69.6, 28.2, 28.0; HRMS calcd for $\mathrm{C}_{14} \mathrm{H}_{13} \mathrm{BrClN}_{2} \mathrm{O}_{5}[\mathrm{M}+\mathrm{H}]^{+}$402.9691, found 402.9694 .

5-(2-(2-Bromo-4-fluorophenoxy)-1-hydroxyethylidene)1,3-dimethylpyrimidine-2,4,6(1H,3H,5H)-trione (BBA27): White solid, yield 57.1\%. m.p. $212 \sim 213{ }^{\circ} \mathrm{C} ;{ }^{1} \mathrm{H}$ NMR (400 MHz, $\left.\mathrm{CDCl}_{3}\right) \delta: 7.34(\mathrm{dd}, J=7.7,3.0 \mathrm{~Hz}, 1 \mathrm{H})$, 6.97 (ddd, $J=9.0,7.7,3.0 \mathrm{~Hz}, 1 \mathrm{H}), 6.83$ (dd, $J=9.1,4.6$ $\mathrm{Hz}, 1 \mathrm{H}), 5.53$ (s, 2H), 3.42 (s, 3H), 3.36 (s, 3H); ${ }^{13} \mathrm{C}$ NMR $\left(100 \mathrm{MHz}, \mathrm{CDCl}_{3}\right) \delta: 193.7,169.6,160.7,157.3(\mathrm{~d}, J=$ $244.5 \mathrm{~Hz}), 151.1$ (d, $J=2.8 \mathrm{~Hz}), 150.1,120.8$ (d, $J=25.8$ $\mathrm{Hz}), 114.8$ (d, $J=22.8 \mathrm{~Hz}), 114.5$ (d, $J=8.5 \mathrm{~Hz}), 112.6$ (d, $J=10.0 \mathrm{~Hz}$ ), 93.9, 70.2, 28.2, 28.0; HRMS calcd for $\mathrm{C}_{14} \mathrm{H}_{13} \mathrm{BrFN}_{2} \mathrm{O}_{5}[\mathrm{M}+\mathrm{H}]^{+}$386.9986, found 386.9988 .

5-(1-Hydroxy-2-(4-phenoxyphenoxy)ethylidene)-1,3dimethylpyrimidine-2,4,6(1H,3H,5H)-trione (BBA-28): White solid, yield 55.2\%. m.p. $125 \sim 127{ }^{\circ} \mathrm{C} ;{ }^{1} \mathrm{H}$ NMR $\left(400 \mathrm{MHz}, \mathrm{CDCl}_{3}\right) \delta: 7.34 \sim 7.27(\mathrm{~m}, 2 \mathrm{H}), 7.06(\mathrm{t}, J=7.4$ $\mathrm{Hz}, 1 \mathrm{H}), 7.00 \sim 6.92(\mathrm{~m}, 6 \mathrm{H}), 5.49(\mathrm{~s}, 2 \mathrm{H}), 3.41(\mathrm{~s}, 3 \mathrm{H})$, $3.36(\mathrm{~s}, 3 \mathrm{H}) ;{ }^{13} \mathrm{C} \mathrm{NMR}\left(100 \mathrm{MHz}, \mathrm{CDCl}_{3}\right) \delta: 194.7,169.6$, $160.7,158.1,154.1,151.1,150.2,129.7,122.7,120.7$, 117.9, 115.9, 94.0, 69.2, 28.1, 28.0; HRMS calcd for $\mathrm{C}_{20} \mathrm{H}_{19} \mathrm{~N}_{2} \mathrm{O}_{6}[\mathrm{M}+\mathrm{H}]^{+}$383.1238, found 383.1240.

5-(1-Hydroxy-2-(naphthalen-2-yloxy)ethylidene)-1,3dimethylpyrimidine-2,4,6(1H,3H,5H)-trione (BBA-29): White solid, yield $49.6 \%$. m.p. $219 \sim 220{ }^{\circ} \mathrm{C} ;{ }^{1} \mathrm{H}$ NMR $\left(400 \mathrm{MHz}, \mathrm{CDCl}_{3}\right) \delta: 7.79 \sim 7.76(\mathrm{~m}, 2 \mathrm{H}), 7.72(\mathrm{~d}, J=8.2$ $\mathrm{Hz}, 1 \mathrm{H}), 7.44$ (t, $J=7.4 \mathrm{~Hz}, 1 \mathrm{H}), 7.35$ (t, $J=7.4 \mathrm{~Hz}, 1 \mathrm{H})$, 7.27 (dd, $J=8.7,2.7 \mathrm{~Hz}, 1 \mathrm{H}), 7.14(\mathrm{~d}, J=2.3 \mathrm{~Hz}, 1 \mathrm{H})$, $5.58(\mathrm{~s}, 2 \mathrm{H}), 3.39(\mathrm{~s}, 3 \mathrm{H}), 3.37(\mathrm{~s}, 3 \mathrm{H}) ;{ }^{13} \mathrm{C}$ NMR $(100$ $\left.\mathrm{MHz}, \mathrm{CDCl}_{3}\right) \delta: 194.3,169.6,160.8,155.7,150.1,134.3$, $129.8,129.4,127.7,126.9,126.6,124.1,118.5,107.1$, 94.0, 68.5, 53.5, 28.1, 28.0; HRMS calcd for $\mathrm{C}_{18} \mathrm{H}_{17} \mathrm{~N}_{2} \mathrm{O}_{5}$ $[\mathrm{M}+\mathrm{H}]^{+}$341.1132, found 341.1133.

5-(2-((1-Bromonaphthalen-2-yl)oxy)-1-hydroxyethylidene)-1,3-dimethylpyrimidine-2,4,6(1H,3H,5H)-trione (BBA-30): White solid, yield 37.1\%. m.p. 235 $237{ }^{\circ} \mathrm{C}$; ${ }^{1} \mathrm{H}$ NMR $\left(400 \mathrm{MHz}, \mathrm{CDCl}_{3}\right) \delta: 8.26(\mathrm{~d}, J=8.7 \mathrm{~Hz}, 1 \mathrm{H})$, 7.79 (d, $J=8.7 \mathrm{~Hz}, 2 \mathrm{H}), 7.60(\mathrm{t}, J=7.2 \mathrm{~Hz}, 1 \mathrm{H}), 7.44$ (t, $J=7.1 \mathrm{~Hz}, 1 \mathrm{H}), 7.19(\mathrm{~d}, J=9.0 \mathrm{~Hz}, 1 \mathrm{H}), 5.71(\mathrm{~s}, 2 \mathrm{H}), 3.42$ $(\mathrm{s}, 3 \mathrm{H}), 3.37(\mathrm{~s}, 3 \mathrm{H}) ;{ }^{13} \mathrm{C} \mathrm{NMR}\left(100 \mathrm{MHz}, \mathrm{CDCl}_{3}\right) \delta$ : $194.0,169.5,160.7,152.3,150.1,133.2,130.3,129.0$, 128.1, 127.9, 126.4, 124.9, 114.7, 93.9, 70.2, 28.1, 28.0; HRMS calcd for $\mathrm{C}_{18} \mathrm{H}_{16} \mathrm{BrN}_{2} \mathrm{O}_{5}[\mathrm{M}+\mathrm{H}]^{+} 419.0237$, found 419.0239 .

5-(2-((1,6-Dibromonaphthalen-2-yl)oxy)-1-hydroxyethylidene)-1,3-dimethylpyrimidine-2,4,6(1H,3H,5H)trione (BBA-31): White solid, yield 34.7\%. m.p. 221 $223{ }^{\circ} \mathrm{C}$; ${ }^{1} \mathrm{H}$ NMR $\left(400 \mathrm{MHz}, \mathrm{CDCl}_{3}\right) \delta: 8.13$ (d, $J=9.0$ $\mathrm{Hz}, 1 \mathrm{H}), 7.95(\mathrm{~s}, 1 \mathrm{H}), 7.75 \sim 7.60(\mathrm{~m}, 2 \mathrm{H}), 7.18$ (d, $J=9.0$ $\mathrm{Hz}, 1 \mathrm{H}), 5.70$ (s, 2H), 3.41 (s, 3H), 3.37 (s, 3H); ${ }^{13} \mathrm{C}$ NMR $\left(100 \mathrm{MHz}, \mathrm{CDCl}_{3}\right) \delta: 193.8,169.6,160.8,152.6,150.1$, $131.8,131.2$, 131.2, 129.9, 128.4, 128.0, 118.9, 115.6, 109.9, 93.9, 70.1; HRMS calcd for $\mathrm{C}_{18} \mathrm{H}_{15} \mathrm{Br}_{2} \mathrm{~N}_{2} \mathrm{O}_{5}[\mathrm{M}+$ $\mathrm{H}]^{+}$496.9342, found 496.9344 .

\subsection{X-ray diffraction of compounds BBA-27 and BBA-29}

BBA-27 and BBA-29 were recrystallized from a mixture of dichloromethane and ethanol (1/1 by volume) to afford a suitable single crystal for each compound. Crystallographic data for compounds BBA-27 and BBA-29 were deposited with the Cambridge Crystallographic Data Centre as supplementary publications with deposition numbers 2002865 and 2002866, respectively. The detailed data can be acquired free of charge via http://www.ccdc.cam.ac.uk/.

\subsection{Herbicidal activity}

The herbicidal activity of the target compounds was evaluated by a previously reported method. ${ }^{[46]}$ The preliminary herbicidal activity was assessed using the Brassica campestris root test and Echinochloa crusgalli cup test. Commercial herbicides 2,4-dichlorophenoxyacetic acid $(2,4-D)$ and mesotrione were selected as positive controls. Further herbicidal activity of the target compounds BBA-22 and BBA-27 against monocotyledonous weeds (Echinochloa crusgalli, Digitaria sanguinalis) and dicotyledonous plants (Brassica campestris, Amaranthus retroflexus) was tested in a greenhouse. Details of the experimental procedure are available in the Supporting Information.

\subsection{Molecular mode of action}

To evaluate the molecular mode of action of the target 
compounds, Arabidopsis thaliana Columbia (Col-0) background was cultivated. The phenotypic, quantitative realtime PCR (qRT-PCR), and compound degradation studies were performed according to a previously described procedure. ${ }^{[46]}$

Supporting Information ${ }^{1} \mathrm{H}$ NMR and ${ }^{13} \mathrm{C}$ NMR spectra of the target compounds. The procedure of herbicidal activity test and evaluation of molecular mode of action. The Supporting Information is available free of charge via the Internet at http://sioc-journal.cn/.

\section{References}

[1] Dumas, E.; Giraudo, M.; Goujon, E.; Halma, M.; Knhili, E.; Stauffert, M.; Batisson, I.; Besse-Hoggan, P.; Bohatier, J.; Bouchard, P.; Celle-Jeanton, H.; Costa Gomes, M.; Delbac, F.; Forano, C.; Goupil, P.; Guix, N.; Husson, P.; Ledoigt, G.; Sarraute, S. J. Hazrd. Mater. 2017, 325, 136.

[2] Park, C. G.; Jang, M.; Shin, E.; Kim, J. Molecules 2017, 22, 1050.

[3] Li, X. C.; Ferreira, D.; Jacob, M. R.; Zhang, Q. F.; Khan, S. I.; ElSohly, H. N.; Nagle, D. G.; Smillie, T. J.; Khan, I. A.; Walker, L. A.; Clark, A. M. J. Am. Chem. Soc. 2004, 126, 6872.

[4] Wu, J. W.; Li, B. L.; Tang, C.; Ke, C. Q.; Zhu, N. L.; Qiu, S. X.; Ye, Y. J. Nat. Prod. 2019, 82, 1917.

[5] Song, J. G.; Su, J. C.; Song, Q. Y.; Huang, R. L.; Tang, W.; Hu, L. J.; Huang, X. J.; Jiang, R. W.; Li, Y. L.; Ye, W. C.; Wang, Y. Org. Lett. 2019, 21, 9579.

[6] Qin, X. J.; Liu, H.; Yu, Q.; Yan, H.; Tang, J. F.; An, L. K.; Khan, A.; Chen, Q. R.; Hao, X. J.; Liu, H. Y. Tetrahedron 2017, 73, 1803.

[7] Carroll, A. R.; Avery, V. M.; Duffy, S.; Forsterd, P. I.; Guymerd, G. P. Org. Biomol. Chem. 2013, 11, 453.

[8] Hellyer, R. O. Aust. J. Chem. 1968, 21, 2825.

[9] Killeen, D. P.; Larsen, L.; Dayan, F. E.; Gordon, K. C.; Perry, N. B.; van Klink, J. W. J. Nat. Prod. 2016, 79, 564.

[10] Igarashi, M.; Tetsuka, Y.; Mimura, Y.; Takahashi, A.; Tamamura, T.; Sato, K. J. Antibiot. 1993, 46, 1843.

[11] Kong, L. Y.; Cui, Q.; Jin, Z.; Xu, X. H. Tetrahedron Lett. 2018, 59, 1705.

[12] Tagasgira, M.; Watanabe, M.; Uemitsu, N. Biosci., Biotechnol., Biochem. 1995, 59, 740.

[13] Senadeera, S. P. D.; Lucantoni, L.; Duffy, S.; Avery, V. M.; Carroll, A. R. J. Nat. Prod. 2018, 81, 1588.

[14] Wang, S. Y.; Lan, X. Y.; Xiao, J. H.; Yang, J. C.; Kao, Y. T.; Chang, S. T. Phytother. Res. 2008, 22, 213.

[15] Christoph, F.; Kaulfers, P. M.; Stahl-Biskup, E. Planta Med. 2001, 67,768 .

[16] van Klink, J. W.; Larsen, L.; Perry, N. B.; Weavers, R. T.; Cook, G. M. Bremer, P. J. Bioorg. Med. Chem. 2005, 13, 6651.

[17] Cacic, M.; Trkovnik, M.; Cacic, F.; Has-Schon, E. Molecules 2006, 11,134 .

[18] Beaudegnies, R.; Edmunds, A. J. F.; Fraser, T. E. M.; Hall, R. G.; Hawkes, T. R.; Mitchell, G.; Schaetzer, J.; Wendeborn, S.; Wibley, J. Bioorg. Med. Chem. 2009, 17, 4134.

[19] Lv, P.; Chen, Y.; Zhao, Z.; Shi, T.; Wu, X.; Xue, J.; Li, Q. X.; Hua, R. J. Agric. Food Chem. 2018, 66, 1023 .

[20] Lei, K.; Sun, D.W.; Hua, X. W.; Tao, Y. Y.; Xu, X. H.; Kong, C. H. Pest Manage. Sci. 2016, 72, 1381.

[21] Shestak, O. P.; Novikov, V. L.; Martyyas, E. A.; Anisimov, M. M. Pharm. Chem. J. 2009, 43, 498.

[22] Gilardoni, G.; Clericuzio, M.; Tosi, S.; Zanoni, G.; Vidari, G. J. Nat. Prod. 2007, 70, 137.

[23] Christoph, F.; Kaulfers, P. M.; Stahl-Biskup, E. Planta Med. 2000, $66,556$.

[24] Khambay, B. P. S.; Beddie, D. G.; Hooper, A. M.; Simmonds, M. S.
J. Tetrahedron 2003, 59, 7131 .

[25] Li, H. B.; Li, L.; Li, J. X.; Han, T. F.; He, J. L.; Zhu, Y. Q. Pest Manage. Sci. 2018, 74, 579.

[26] Wang, D. W.; Lin, H. Y.; He, B.; Wu, F. X.; Chen, T.; Chen, Q.; Yang, W. C.; Yang, G. F. J. Agric. Food Chem. 2016, 64, 8986.

[27] Wang, D. W.; Lin, H. Y.; Cao, R. J.; Ming, Z. Z.; Chen, T.; Hao, G. F.; Yang, W. C.; Yang, G. F. Pest Manage. Sci. 2015, 71, 1122

[28] Wang, D. W.; Lin, H. Y.; Cao, R. J.; Chen, T.; Wu, F. X.; Hao, G. F.; Chen, Q.; Yang, W. C.; Yang, G. F. J. Agric. Food Chem. 2015, 63, 5587.

[29] Wang, D. W.; Lin, H. Y.; Cao, R. J.; Yang, S. G.; Chen, Q.; Hao, G. F.; Yang, W. C.; Yang, G. F. J. Agric. Food Chem. 2014, 62, 11786.

[30] Palwinder Singh, S. Eur. J. Med. Chem. 2014, 74, 440.

[31] Singh, P.; Kaur, M.; Verma, P. Bioorg. Med. Chem. Lett. 2009, 19, 3054.

[32] Siddiqui, Z. N.; Musthafa, T. N. M.; Ahmad, A.; Khan, A. U. Bioorg. Med. Chem. Lett. 2011, 21, 2860.

[33] Yan, Q.; Cao, R. H.; Yi, W.; Chen, Z. Y.; Wen, H.; Ma, L.; Song, H. C. Eur. J. Med. Chem. 2009, 44, 4235.

[34] Neumann, D. M.; Cammarata, A.; Backes, G.; Palmer, G. E.; Jursic, B. S. Bioorg. Med. Chem. 2014, 22, 813.

[35] Gao, Y.; Xie, J. S.; Tang, R. T.; Yang, K. Y.; Zhang, Y. H.; Chen, L. X.; Li, H. Bioorg. Chem. 2019, 85, 168.

[36] Laxmi, S. V.; Reddy, Y. T.; Kuarm, B. S.; Reddy, P. N.; Crooks, P. A.; Rajitha, B. Bioorg. Med. Chem. Lett. 2011, 21, 4329.

[37] Freeman-Cook, K. D.; Reiter, L. A.; Noe, M. C.; Antipas, A. S.; Danley, D. E.; Datta, K.; Downs, J. T.; Eisenbeis, S.; Eskra, J. D.; Garmene, D. J.; Greer, E. M.; Griffiths, R. J.; Guzman, R.; Hardink, J. R.; Janat, F.; Jones, C. S.; Martinelli, G. J.; Mitchella, P. G.; Yocuma, S. A. Bioorg. Med. Chem. Lett. 2007, 17, 6529.

[38] Kim, S. H.; Pudzianowski, A. T.; Leavitt, K. J.; Barbosa, J.; McDonnell, P. A.; Metzler, W. J.; Rankin, B. M.; Liu, R.; Vaccaro, W.; Pitts, W. Bioorg. Med. Chem. Lett. 2005, 15, 1101.

[39] Cordato, D. J.; Herkes, G. K.; Mather, L. E.; Morgan, M. K. J. Clin. Neurosci. 2003, 10, 283.

[40] Willow, M.; Johnston, G. A. R. Int. Rev. Neurobiol. 1983, 24, 15.

[41] Reddy, Y. T.; Sekhar, K. R.; Sasi, N.; Reddy, P. N.; Freeman, M. L.; Crooks, P. A. Bioorg. Med. Chem. Lett. 2010, 20, 600

[42] Altowyan, M. S.; Barakat, A.; Soliman, S. M.; Al-Majid, A. M.; Ali, M.; Elshaier, Y. A. M. M.; Ghabbour, H. A. J. Mol. Struct. 2019, 1175,524

[43] Haldar, M. K.; Scott, M. D.; Sule, N.; Srivastavab, D. K.; Mallik, S. Bioorg. Med. Chem. Lett. 2008, 18, 2373.

[44] Guerin, D. J.; Mazeas, D.; Musale, M. S.; Naguib, F. N. M.; Safarjalani, O. N. A.; Kouni, M. H.; Panzica, R. P. Bioorg. Med. Chem. Lett. 1999, 9, 1477.

[45] Lee, D. L.; Carter, C. G. US4797147, 1989

[46] Lei, K.; Li, P.; Yang, X. F.; Wang, S. B.; Wang, X. K.; Hua, X. W.; Sun, B.; Ji, L. S.; Xu, X. H. J. Agric. Food Chem. 2019, 67, 10489.

[47] Lei, K.; Liu, Y.; Wang, S. B.; Sun, B.; Hua, X. W.; Xu, X. H. Chem. Res. Chin. Univ. 2019, 35, 609.

[48] Li, N.; Fu, L. L.; Wang, S. B.; Liu, Y.; Lei, K.; Xu, X. H. J. Liaocheng Univ. (Nat. Sci. Ed.) 2018, 31, 53 (in Chinese). (李娜, 付琳琳, 王世本, 刘洋, 雷康, 徐效华, 聊城大学学报 (自然科学版), 2018, 31, 53.)

[49] Xu, C.; Zhang, Y.; Yu, Y.; Li, Y.; Wei, S. Bioelectromagnetics 2018, $39,15$.

[50] Song, Y. J. Integr. Plant Biol. 2014, 56, 106.

[51] Scherer, G. F. E.; Zahn, M.; Callis, J.; Jones, A. M. FEBS Lett. 2007, 581, 4205 .

[52] Raghavan, C.; Ong, E. K.; Dalling, M. J.; Stevenson, T. W. Funct. Integr. Genomics 2006, 6, 60 .

[53] Bayramoğlu, D.; Kurtay, G.; Güllü, M. Synth. Commun. 2020, 50, 649.

[54] Thinnes, C. C.; Lohans, C. T.; Abboud, M. I.; Yeh, T. L.; Tumber, A.; Nowak, R. P.; Attwood, M.; Cockman, M. E.; Oppermann, U.; Loenarz, C.; Schofield, C. J. Chem. Eur. J. 2019, 25, 2019. 